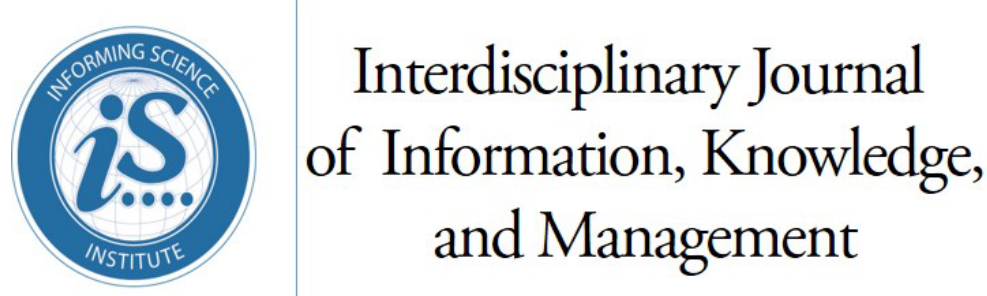

An Official Publication

of the Informing Science Institute

InformingScience.org

IJIKM.org

Volume 162021

\title{
THE INFLUENCE OF SOFT SKILLS ON EMPLOYABILITY: A CASE STUdy ON TECHNOLOGY INDUSTRY SECTOR IN MALAYSIA
}

\begin{tabular}{lll}
\hline Sally S. Fadhil* & $\begin{array}{l}\text { Universiti Pindidikan Sultan Idris, Faculty } \\
\text { of Management and Economic, Perak, } \\
\text { Malaysia. }\end{array}$ & \\
Ramlee Ismail & $\begin{array}{l}\text { Universiti Pindidikan Sultan Idris, Faculty } \\
\text { of Management and Economic, Perak, } \\
\text { Malaysia. }\end{array}$ & \\
Alhamzah Alnoor & $\begin{array}{l}\text { Department of Business Management } \\
\text { Techniques, Management Technical } \\
\text { College, Southern Technical University, }\end{array}$ & \\
& Basrah, Iraq.
\end{tabular}

\section{ABSTRACT}

Aim/Purpose

This research investigates the influence of soft skills on graduates' employability in the technology industry, using the technology industry sector in Malaysia as a case.

Background

Organizations are looking for appropriate mechanisms to hire qualified employees with strong soft skills and hard skills. This requires that job candidates possess a set of qualifications and skills which impact their employability.

Methodology $\quad$ Fuzzy Delphi analysis was conducted as preliminary study to identify the critical soft skills required by technology industry sector. The preliminary study produced ten critical soft skills to form a conceptual model of their influence on employability. Then, an online questionnaire survey was distributed in two industry companies in Malaysia to collect research data, and regression analysis was conducted to validate the conceptual model.

Contribution This research focuses on the influence of soft skills on graduate employability in the technology industry sector, since the selection of the best candidate in the industry will improve employee performance and lead to business success.

Accepting Editor Christine Nya-Ling TAN | Received: April 1, 2021 | Revised: May 30, June 8, June 11, 2021 | Accepted: June 12, 2021.

Cite as: Fadhil, S. S., Ismail, R., \& Alnoor, A. (2021). The influence of soft skills on employability: A case study on technology industry sector in Malaysia. Interdisciplinary Journal of Information, Knowledge, and Management, 16, 255-283. https://doi.org/10.28945/4807

(CC BY-NC 4.0) This article is licensed to you under a Creative Commons Attribution-NonCommercial 4.0 International License. When you copy and redistribute this paper in full or in part, you need to provide proper attribution to it to ensure that others can later locate this work (and to ensure that others do not accuse you of plagiarism). You may (and we encourage you to) adapt, remix, transform, and build upon the material for any non-commercial purposes. This license does not permit you to use this material for commercial purposes. 
Findings

Recommendations for Practitioners

Impact on Society

Future Research
The results of regression analysis confirmed that Communication skills, Attitude, Integrity, Learnability, Motivation, and Teamwork are significantly correlated with employability, which means that these soft skills are the critical factors for employability in Malaysian technology companies.

The model proposed in this article can be used by employers to give better assessment of candidates' compatibility with the jobs available.

This research highlights the critical soft skills required by technology industry sector, which will reduce the unemployment percentages among graduates.

More studies are required to examine the soft skills found in the literature and to define the most important skills from a general perspective of the industry. Future research should assess the moderating role of other variables, such as skills gap, employee performance, and employee knowledge. Furthermore, it is recommended to conduct similar studies of soft skills for employability in other countries.

Keywords soft skills, human development, unemployment, industry, employability, human resource

\section{INTRODUCTION}

According to the human capital theory, an essential rule in measuring the quality of human capital is through educational achievement (Ramlee \& Marinah, 2013). However, the changes and challenges of economy in today's globalization require both hard and soft skills. Hence, all organizations are calling for soft skills since these skills would enhance their competitiveness and growth. Nevertheless, these skills are not possessed by graduates, even though they have a good level of hard skills (i.e., technical knowledge and competency) (Hassan, 2015). The most common and trending topic on the employment/unemployment ratio of people is based on the soft skills deficiency: the skills that are required for handling the latest development of industries (Clarke, 2018).

In Malaysia, one of the key challenges in the industry is the lack of soft skills among graduates (Ministry of Higher Education Malaysia ([MOHE], 2012). Initially, universities worldwide faced severe criticism that their curricula were not sufficient to train graduates with the required soft skills. Hence, graduates are still struggling to find jobs, although their grades are improving (Hassan, 2015). Furthermore, many graduates are not ready for today's workplace due to their lack of communication skills, teamwork skills, and ability to handle projects independently. Therefore, the necessary skills needed to compete in the workplace must be defined clearly (Seetha, 2014). In literature, researchers concluded that low rate of graduates' employability is a result of the gap between curricula of universities and the required skills in industries (Tapsir, 2017). The current labour market in Malaysia needs more competency and soft skills from graduates (Y. M. Adnan et al., 2017).

Selection of qualified human resources is a key success factor for organizations (AlQudah et al., 2014). It is crucial to employ a highly skilled workforce to remain competitive and productive in the global marketplace (Williams, 2015). Hence, employers are increasingly looking for highly skilled employees, where the soft skills are required within the work environment (Yusoff et al., 2012). Unfortunately, a substantial percentage of local graduates in Malaysia are still missing appropriate soft skills, which will lead to increase of unemployment (Hairi et al., 2011; Rahman et al., 2017). Furthermore, several factors might increase the percentage of unemployed graduates, which may include personality reflecting absence of confidence throughout interviews mismatch between personal quality and industry demand, and poor communication skills (Hassan, 2015).

The industrial growth, quality of products and services, and individuals' behaviour in the industrial environment are strongly based on the soft skills that employees possess. The financial result and achievement of any industry is strongly dependent on the soft skill of its employees (Cimatti, 2016). 
This is why many industries are now focusing on the soft skill of their employees. In addition, the advancement of technologies and virtual workplaces (which include some situations like work from home) turns more industrial attention to improving the soft skills of its employees (Dall'Amico \& Verona, 2015). According to the Organization for Economic Co-operation and Development [OECD] survey in 2019, the economy of Malaysia has significant performance compared to other developing countries. The reason behind this is that Malaysia has a strong and stable financial sector that makes the domestic product constantly increase with improving productivity and employment effectiveness, in addition to promoting entrepreneurship, investment and the efficient implementation of measures for household income (OECD, 2019). The current industrialization situation of Malaysia requires more people with high education and high competency for the technologically changing workplace. Hence, improving graduates' soft skill is a necessity of time (Y. M. Adnan et al., 2017).

The economy of Malaysia has shifted from relying on the agricultural system and exports of raw materials to a diversified economy that includes the export of high-precision electronics. This is due to the adoption of research and development in Malaysia which played a major role in pushing forward a knowledge-based economy (Akoum, 2016). The technology industry sector is the future of manufacturing, where conventional models are making the way for greater technology adoption for efficiency and flexibility towards sustaining competitiveness in labour market (Ministry of International Trade and Industry [MITI], 2018). Based on the World Bank reports, the technology industry is impactful on the economy to keep pace with the global economic development (Raja et al., 2013; World Bank, 2020). Furthermore, the Department of Statistics Malaysia (2020) reported in its official portal that the technology has contributed around RM 289.2 billion Ringgit to the economy. As a result, the technology industry sector of Malaysia was selected as the case for this study to measure the influence of soft skills on graduates' employability.

This research aims to identify the critical soft skills required by the technology industry sector, first by consolidating soft skills found in the literature into critical dimensions and then by determining their significant impact of employability through regression analysis of survey data. The paper's content is organized as follows. First, a brief description is given about the theories related to employability and soft skills. Next, the research methodology of this research is presented. This section includes research design, research conceptual framework, the questionnaire design, population and sample size, and data analysis methods. After that, the results are discussed to explore the findings of this research, in terms of descriptive statistics, validity assessments, and soft skills description and evaluation. Finally, the conclusion is presented to summarise the research findings.

\section{THEORIES RELATED TO EMPLOYABILITY AND SOFT SKILLS}

The theoretical debate on soft skills and employability is related to human capital theory and to human development or capabilities theory (Jonck, 2014). The human capital theory termed education as an essential key in building economy and treated it as an essential aspect to be competent in global economic advancements (Becker, 2009; Bridgstock, 2009; Rothwell \& Arnold, 2007; Van Loo \& Rocco, 2004). When analysing the employability of students from the companies' perspective, the skills and knowledge of employed graduates are being analysed by emphasising a human capital approach to graduates' employability skills (Jonck, 2014). Human capabilities or development emphasize a majority of principles involving professional preparation, knowledge generation, public sphere enlightenment, and cultural knowledge (McLean et al., 2012). The human capabilities or development theory looks at graduates' employability from the resources point of view. However, human capital theory highlights education as the key enabler of economy and global economic participation (Bridgstock, 2009). Employers are considering qualified labour as production and success factors. The human capital term is utilised to reflect the quality of labour, hence the knowledge and skills (Mohr \& Seymore, 2018). 
The consensus theory aligns with the human capital theory. It provides an information for modifying the relation between institutions, organizations, and workplaces using employability (P. Brown et al., 2003). It concentrates on the social belief that people have mutuality between them (Selvadurai et al., 2012). According to consensus theory, the advancement of generic abilities can improve the employability of students and guide them to perform task at workplace. The focus of this theory is to grab and share the information which includes analysis. Furthermore, it indicates that students should be capable to communicate and represent the information with industrial standards. This includes writing emails, giving presentations, and team discussions. Additionally, it also suggests enhancing creativity and problem-solving skills, which are very important in uncertain situations. Along with these three points, students must have interaction skills, which means being more sociable; this could help a project or an industry in the form of teamwork or leadership. Hence, addition of these skills in the university syllabus is essential to produce graduates with soft skills capabilities. It is necessary to adopt these skills in every individual in such fast-growing industrialization changes. Therefore, it is essential for universities and institutes to review the current curricula and update them with the latest changes (Selvadurai et al., 2012). This shows the requirements and necessity of soft skills in employability. Along with this, it also indicates the alignment between industrial requirements and the ways through which students can learn the required knowledge (Selvadurai et al., 2012).

P. Brown et al. (2003) explained conflict theory as the conflict between three different groups, which are employment provider, graduate or employee, and trainee, with different levels of opportunity to enhance employability. In the capital-labour conflict there was a debate regarding the role of employers that impacts the required skills, and employees not acquiring these skills through the proper trainings provided by employers (Selvadurai et al., 2012). The employer-educator conflict suggests that the higher institutions are not providing the knowledge, proper training, practical knowledge to accomplish the technical objectives, and the soft skills to graduates. This conflict targets the employer for not providing the opportunity to enhance work experience in workplace and institutional trainers to redesign the current curriculum with latest knowledge base and an optimised method to teach or transfer this knowledge.

The control theory is relevant in soft skills measuring and assessment research, which defines the analysis through control systems and feedback loops (Carver \& Scheier, 1982). Self-regulation is mandatory for its effective operation. Self-regulation is dependent on the feedback loop. Feedback is the sensed deviation between the reference and actual values of system parameters. Further analysis is required to report the performance, the gap, and the data to minimise the discrepancy. With this theory, employers may send the questionnaire assessment feedback back to candidates, so they are aware of what kind of skills they have and what are the lacking skills that led to missing the job opportunity. The efficient soft skill analysis and measurement that are consistent with theory should define the system parameters, meaning it should define the required soft skills. However, defining the soft skill in complete detail and providing complete detail about feedback may fail to inspire the graduates to learn and improve the missing skills (Gibb, 2014).

The research theories and domains can be summarised in Figure 1. The main domain describes the relationship between soft skills and employability to increase graduates' competency in the labour market. The human capital and consensus theories support the first domain. Next is the second domain, which emphasizes the soft skills and employability assessment for graduates and current employees. The theory related to this domain is the conflict theory. Finally, the third domain is the soft skills model and instrument development. Through this domain the proposed model and instrument would be developed to ease the assessment of soft skills' influence on employability. The related theory to this domain is the control theory. 


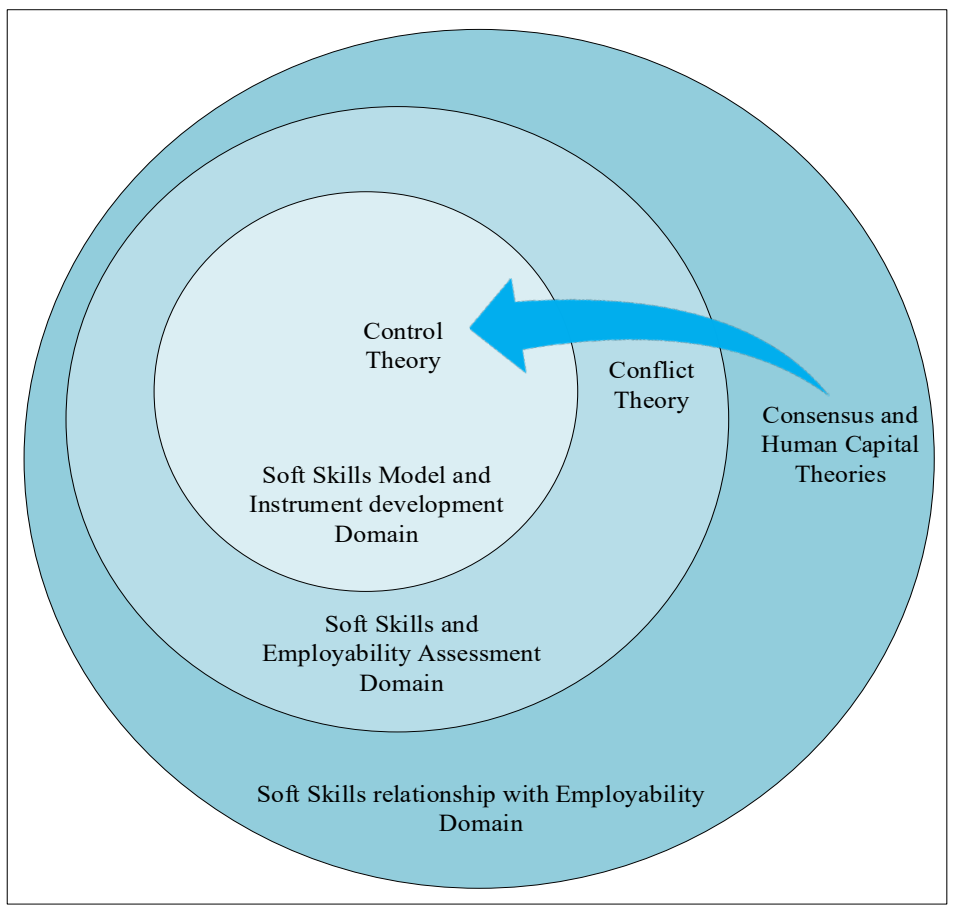

Figure 1: Research Domains and Related Theories

\section{RESEARCH METHODOLOGY}

\section{RESEARCH DESIGN AND METHODS}

This study utilised a quantitative design to measure the influence of critical soft skills on graduates' employability in the technology industry sector of Malaysia. Human nature and environment are complex fields to analyse using the statistical methods, hence a better replacement for numerical analysis is required. This research does not attempt to create a new theory, but rather aims to answer current research questions using the analysis of questionnaire responses through regression analysis. This research explores and understands the soft skills role in improving the employability of graduates in technology companies of Malaysia. To achieve this goal, this study used the Fuzzy Delphi Method for a preliminary study analysis. Furthermore, it explored employer perceptions on the necessity of soft skill with respect to workplace requirements within technology industry. The overall flow of research design methodology is illustrated in Figure 2. 


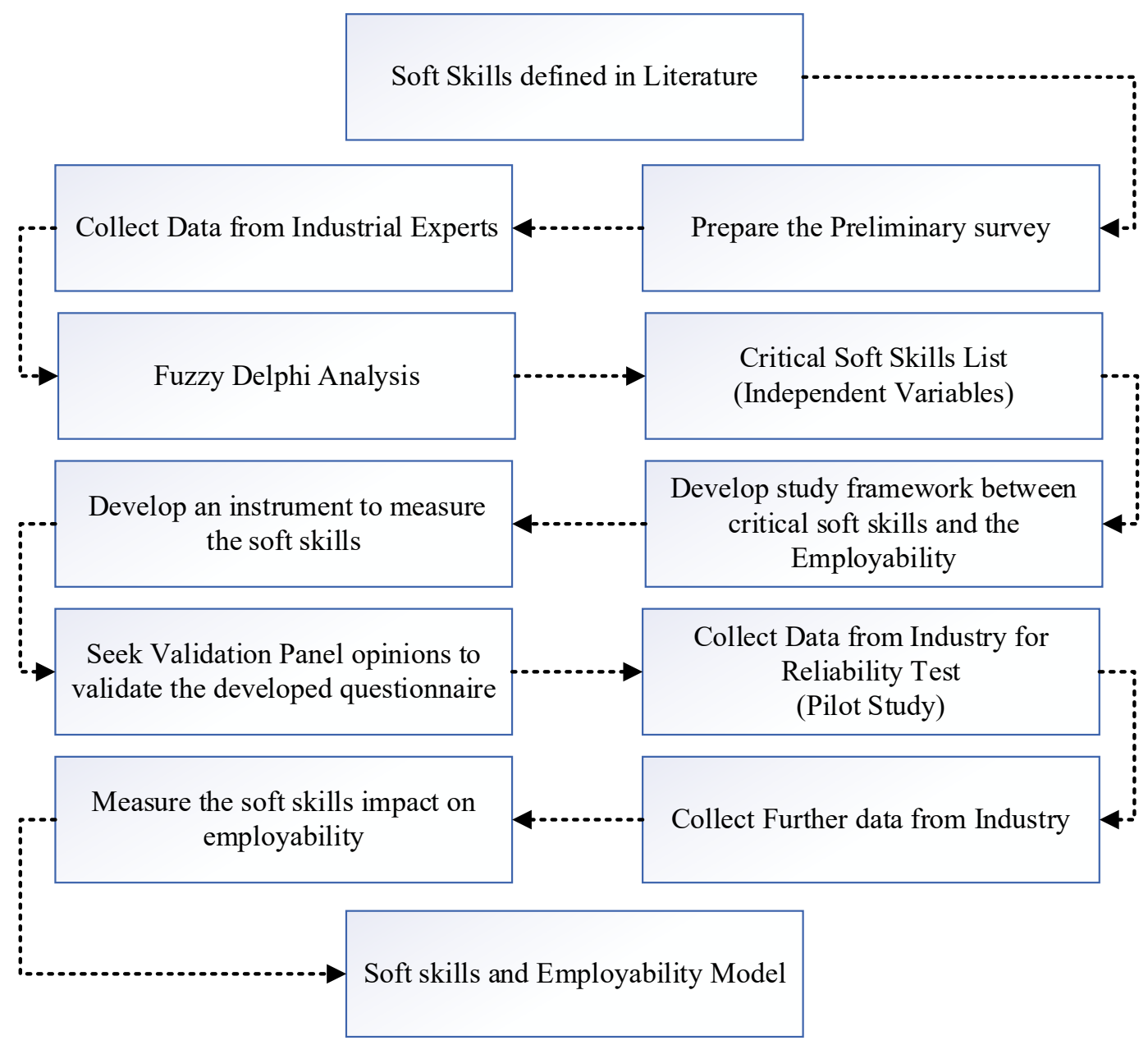

Figure 2: Overall Research Methodology

\section{PRELIMINARY STUDY TO IDENTIFY AND CONSOLIDATE SOFT SKILLS FROM LITERATURE}

The first step was identification of soft skills covered in the literature, which yielded a total of $27 \mathrm{soft}$ skills (as listed in Appendix A, Figure A1). A large number of variables (i.e., soft skills) will increase the research complexity. Hence, this study utilised a preliminary study analysis based on the Fuzzy Delphi Method to reduce the number of independent variables by consolidating the critical soft skills based on technology industry experts' feedback.

The Fuzzy Delphi Method, proposed by (Ishikawa et al., 1993), is the modified and enhanced version of the classical Delphi technique -- an integration with the fuzzy set theory. The main aim of the Delphi method was to achieve a consensus based on the votes, rankings, or other forms of input provided by the experts (H.-Y. Tsai et al., 2010) through multiple iterations of polling with a questionnaire (Helmer-Hirschberg, 1967). The iterative process stops when all experts on the panel reach a final consensus. This technique was used to achieve "anonymity," "iteration," "controlled feedback," and "statistical group response" (Rowe \& Wright, 1999). Integration of fuzzy system in the Delphi Method can solve the problem of fuzziness. This integration uses semantic variables as a solution to fuzziness issue in the Delphi Method (Habibi et al., 2015). The process of Fuzzy Delphi Method is illustrated in Appendix B. 
The number of experts required by Fuzzy Delphi analysis based on previous studies recommendations is 10 to 15 participants (Delbecq et al., 1975; Manakandan et al., 2017; H.-C. Tsai et al., 2020). Those experts were identified based on their experience in interviews and hiring processes of their companies. For this study, 15 experts were recruited from technology companies in Malaysia, of which 10 from Intel Corporation and 5 from Analog Devices company. The opinions of these experts were surveyed, as they have a role in providing advice on employment opportunities and soft skills requirements for jobs. The survey questionnaire consists of 27 questions, one for each of the soft skill identified from the literature, and the questions are on the 5-point Likert scale, with the five levels being "Very Important", "Important", "Neutral", "Not Important", and "Not Important at All", numbered inversely with integers 1 through 5, as shown in Appendix B (Table B1).

\section{Table 1: Characteristics of Experts Included in Fuzzy Delphi Analysis}

\begin{tabular}{|c|c|l|c|}
\hline Expert & Age & Job Title & Years of experience \\
\hline 1 & $41-50$ & Senior Manager & $11-15$ \\
\hline 2 & $31-40$ & Team Leader & $6-10$ \\
\hline 3 & $41-50$ & Manager & $11-15$ \\
\hline 4 & $31-40$ & Team Leader & $6-10$ \\
\hline 5 & $31-40$ & Team Leader & $6-10$ \\
\hline 6 & $41-50$ & Manager & $11-15$ \\
\hline 7 & $41-50$ & Senior Manager & $11-15$ \\
\hline 8 & $41-50$ & Director & $16-20$ \\
\hline 9 & $31-40$ & Senior Manager & $11-15$ \\
\hline 10 & $31-40$ & Manager & $6-10$ \\
\hline 11 & $31-40$ & Contributor & $11-15$ \\
\hline 12 & $31-40$ & Contributor & $11-15$ \\
\hline 13 & $41-50$ & Contributor & $6-10$ \\
\hline 14 & $31-40$ & Contributor & $11-15$ \\
\hline 15 & $31-40$ & Contributor & $6-10$ \\
\hline
\end{tabular}

Table 1 shows the description of the characteristics of the experts who were asked about their opinions for the critical soft skills requirements in industry. The results of Table 1 indicates that the ages of the experts ranged from 31 to 50 years with different job titles, which include Senior Manager, Team Leader, Manager, Director, and Individual Contributor. Those experts had a range of experience from 6 to 15 years. This study targeted managers and senior engineers to get opinions of required soft skills from the management and technical perspectives.

The output of the Fuzzy Delphi analysis was ten soft skills as shown in Figure 3, and the statistical results of Fuzzy Delphi Analysis are included in Appendix C.

\section{CONCEPTUAL FRAMEWORK}

The ten soft skills emerging from consolidation with the Fuzzy Delphi method were taken in this research as the most critical ones required in the technology industry in Malaysia. They, as the core dimensions of "soft skills", were formulated into ten hypotheses in relation to employability, which in turn formed the conceptual framework (Figure 3).

The conceptual framework was based on previous studies. Specifically:

- Employability depends on employee's ability to adopt the main soft skills (Ajit \& Deshmukh, 2013; Suarta et al., 2017).

- To carefully understand the soft skills, the approach should be process-oriented not function-oriented (Rahmat et al., 2017). 
- Soft skills are an appropriate approach for enhancing the employability (Rahmat et al., 2017; Singh et al., 2017).

- Successful implementation of the factors of soft skills leads to the improvement of employability (Hamid et al., 2014).

The analysis above suggests the following hypotheses to test, in order to achieve the research objectives of defining the most influential soft skills on employability of graduates in technology industry:

- H1: Trust has a significant impactful on Employability.

- H2: Honesty has a significant impactful on Employability.

- H3: Responsibility has a significant impactful on Employability.

- H4: Communication skills have a significant impactful on Employability.

- H5: Teamwork has a significant impactful on Employability.

- H6: Learnability has a significant impactful on Employability.

- H7: Attitude has a significant impactful on Employability.

- H8: Integrity has a significant impactful on Employability.

- H9: Motivation has a significant impactful on Employability.

- H10: Innovation has a significant impactful on Employability.

The Dependent Variable (DV) in this study is Employability (Ajit \& Deshmukh, 2013; Martin Sanchis, 2017; Nizam \& Badri, 2013; Paranjape, 2007; Sumanasiri, 2015). Independent variables (IV) of this research are the soft skills extracted from the preliminary study results.

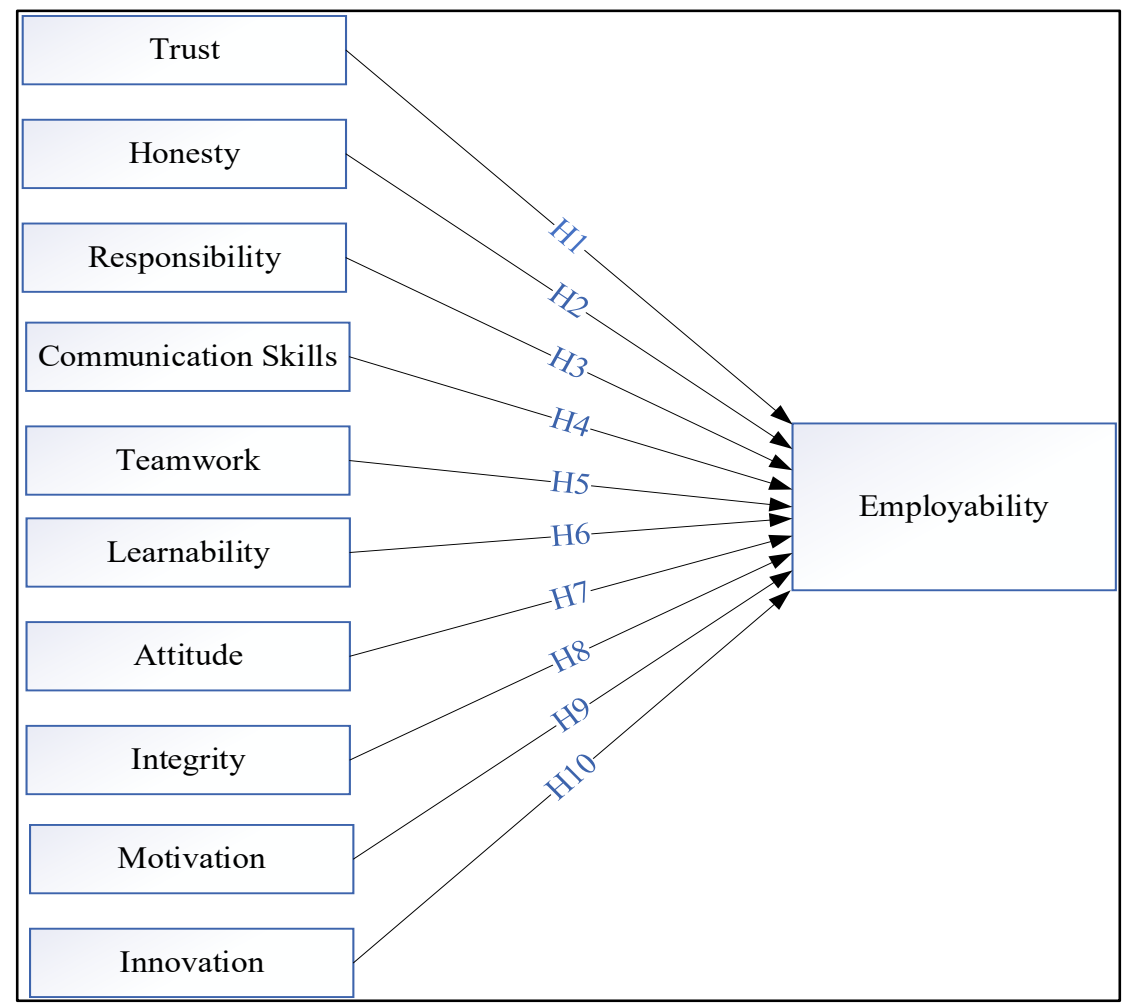

Figure 3: Conceptual Framework 


\section{MEASUREMENT INSTRUMENT (QUESTIONNAIRE)}

For the main study, a survey questionnaire including both independent factors (core soft skills) and dependent variable (employability) was developed by combing corresponding factor-measuring instruments from previous studies (see Table 2). Specifically, the questionnaire consists of 55 question items using the 5-point Likert scale (very likely $=5$, likely $=4$, neutral $=3$, unlikely $=2$, very unlikely $=1$ ), addressed soft skills as multi-dimensional independent variable (e.g., Boe, 2002; Heijde \& Van Der Heijden, 2006; Hoch, 2013; Jackson, 1994; Norizan et al., 2018), and employability (dependent variable) as one-dimensional variable (Dillahunt et al., 2016; Park, 2020).

Table 2: Adoption of Factor-Measuring Instruments from Literature

\begin{tabular}{|l|l|c|l|}
\hline \multicolumn{1}{|l|}{ Variables } & Items & Authors \\
\hline \multirow{5}{*}{} & Trust & 4 & (Boe, 2002; Hoch, 2013) \\
\cline { 2 - 4 } & Honesty & 4 & (Magnússon, 2017; Zahari et al., 2019) \\
\cline { 2 - 5 } & Responsibility & 4 & $\begin{array}{l}\text { (Norizan et al., 2018; Singh et al., 2017; Tribble, } \\
\text { 2009; Zahari et al., 2019) }\end{array}$ \\
\cline { 2 - 5 } & $\begin{array}{l}\text { Communication } \\
\text { Skills }\end{array}$ & 4 & $\begin{array}{l}\text { (Balcar, 2016; Kenayathulla, 2019; Norizan et al., } \\
\text { 2018; Singh et al., 2017) }\end{array}$ \\
\cline { 2 - 5 } & Teamwork & 4 & $\begin{array}{l}\text { (Jackson, 1994; Norizan et al., 2018; Whitehurst, } \\
\text { 2016) }\end{array}$ \\
\cline { 2 - 5 } & Learnability & 4 & $\begin{array}{l}\text { (A. H. M. Adnan et al., 2014; Norizan et al., 2018; } \\
\text { Singh et al., 2017; Tribble, 2009) }\end{array}$ \\
\cline { 2 - 5 } & Attitude & 4 & (Norizan et al., 2018; Whitehurst, 2016) \\
\cline { 2 - 4 } & Integrity & 4 & (Hoch, 2013; Zahari et al., 2019) \\
\cline { 2 - 5 } & Motivation & 4 & $\begin{array}{l}\text { (Magnússon, 2017; Norizan et al., 2018; Tribble, } \\
\text { 2009) }\end{array}$ \\
\cline { 2 - 4 } & Innovation & 4 & (Hoch, 2013; Jackson, 1994; Singh et al., 2017) \\
\hline Employability & 15 & (Heijde \& Van Der Heijden, 2006) \\
\hline
\end{tabular}

\section{SURVEY POPULATION \& SURVEY DISTRIBUTION}

In order to test the hypotheses, an online survey was conducted using the questionnaire instrument described above to collect quantitative data for PLS (regression) analysis. A pool of recipients was constructed for survey distribution, using the stratified random sampling method, including all employees of the two chosen companies, Intel Corporation and Analog Devices. The survey was distributed to 472 employees, by sharing a link to the survey website with help by five managers. In total, 350 responses were collected, of which 5 responses were incomplete and consequently ignored, leaving 345 valid ones for analysis, which yield a response rate of $74.15 \%$.

Table 3 presents demographic distributions of the survey participants. As shown, $8.70 \%$ of the survey participants were Manager, 6.38\% were Senior Manager, 57.68\% were Individual Contributor, and $27.25 \%$ were Team Leader. Furthermore, $5.80 \%$ of the study sample individuals' Years of Experience were Less than a Year, $25.80 \%$ were $1-3$ years, $30.72 \%$ were $4-6$ years, $26.09 \%$ were $7-9$ years, $8.12 \%$ were $10-12$ years, and $3.48 \%$ were More than 12 years. 
Table 3: Sample Characteristics Data Summary $(n=345)$

\begin{tabular}{|c|c|c|c|c|}
\hline No. & \multicolumn{2}{|l|}{ Answers } & Frequency & $\begin{array}{c}\text { Number of } \\
\text { Answers }\end{array}$ \\
\hline \multirow{7}{*}{1} & \multirow{7}{*}{ Age } & Under 18 & $0.00 \%$ & 0 \\
\hline & & $18-24$ & $20.29 \%$ & 70 \\
\hline & & $25-34$ & $41.45 \%$ & 143 \\
\hline & & $35-44$ & $28.99 \%$ & 100 \\
\hline & & $45-54$ & $8.70 \%$ & 30 \\
\hline & & $55-64$ & $0.58 \%$ & 2 \\
\hline & & $65+$ & $0.00 \%$ & 0 \\
\hline \multirow{7}{*}{2} & \multirow{7}{*}{ Departments } & Human Resources & $14.49 \%$ & 50 \\
\hline & & Engineering & $46.38 \%$ & 160 \\
\hline & & Information Technology & $17.39 \%$ & 60 \\
\hline & & Finance & $5.80 \%$ & 20 \\
\hline & & Services & $10.14 \%$ & 35 \\
\hline & & Customer Support & $5.80 \%$ & 20 \\
\hline & & Other (please specify) & $0.00 \%$ & 0 \\
\hline \multirow{7}{*}{3} & \multirow{7}{*}{ Job Title } & Manager & $8.70 \%$ & 30 \\
\hline & & Senior Manager & $6.38 \%$ & 22 \\
\hline & & Director & $0.00 \%$ & 0 \\
\hline & & Individual Contributor & $57.68 \%$ & 199 \\
\hline & & Team Leader & $27.25 \%$ & 94 \\
\hline & & $\mathrm{CEO}$ & $0.00 \%$ & 0 \\
\hline & & Other (please specify) & $0.00 \%$ & 0 \\
\hline \multirow{6}{*}{4} & \multirow{6}{*}{$\begin{array}{l}\text { Years of } \\
\text { Experience }\end{array}$} & Less than a Year & $5.80 \%$ & 20 \\
\hline & & $1-3$ & $25.80 \%$ & 89 \\
\hline & & $4-6$ & $30.72 \%$ & 106 \\
\hline & & $7-9$ & $26.09 \%$ & 90 \\
\hline & & $10-12$ & $8.12 \%$ & 28 \\
\hline & & More than 12 years & $3.48 \%$ & 12 \\
\hline
\end{tabular}

\section{DATA ANALYSIS \& MODEL VALIDATION}

The Partial Least Square (PLS) modelling was utilised to evaluate the study framework using SmartPLS v3.0, since it analyses the data regardless of the sample size and normality. Furthermore, SmartPLS has superior ability to predict and explore cause-effect relationships (Ringle et al., 2005). The discriminant and convergent validity were measured before examining the study model hypotheses. After that, the details were grouped by metrics signifying the main variables and their dimensions for the dependent variable (Hair et al., 2014). The criteria to examine closer suitability comprised factor loading, which should be greater than 0.7; Average Extracted Variance (AVE) should be greater than 0.4; Cronbach's Alpha (CA) and Combined Reliability (CR) of internal consistency reliability should exceed 0.7 (Hair et al., 2014). 


\section{RESULTS AND DISCUSSIONS}

\section{DESCRIPTIVE STATISTICS}

The standard deviation values of variables listed in Table 4 show slight discrepancies between the opinions of experts. Furthermore, the arithmetic means are between 4 to 5 , closer to 5 (which corresponds to "Very Likely").

Table 4: Mean and Standard Deviation

\begin{tabular}{|l|c|c|}
\hline Soft Skill & Mean & SD \\
\hline Learnability & 4.933 & 0.258 \\
\hline Responsibility & 4.933 & 0.258 \\
\hline Teamwork & 4.866 & 0.351 \\
\hline Communication Skills & 4.866 & 0.351 \\
\hline Motivation & 4.866 & 0.351 \\
\hline Trust & 4.866 & 0.351 \\
\hline Honesty & 4.866 & 0.351 \\
\hline Innovation & 4.800 & 0.560 \\
\hline Integrity & 4.800 & 0.414 \\
\hline Attitude & 4.400 & 0.632 \\
\hline
\end{tabular}

\section{VALIDITY ASSESSMENT OF INSTRUMENT}

\section{Reliability test}

Reliability refers to how consistent the measurement is (Drost, 2011; Henseler et al., 2015) and whether the measurement used is stable and produces the expected result (Considine et al., 2005). A study is considered reliable if the result produced by an instrument is consistent (Mercer et al., 2008). According to Drost (2011), the coefficient alpha is a widely known technique used to test the consistency in behavioural sciences. Given that the coefficient alpha was introduced by Lee Cronbach in 1951, the technique was named Cronbach's Alpha (CA). CA testing was the most accepted test that ensures reliability in social research (Sekaran \& Bougie, 2016). In reliability analysis, CA that approaches 1.0 indicates a high internal consistency reliability (J. D. Brown, 2002; Cronbach, 1946). A pilot test was carried out in Penang, Malaysia prior to the actual data gathering for this research. Fifty questionnaires were distributed within National Instruments company. However, after removing incompletely answered questionnaires, 45 questionnaires were used. Connelly (2008) suggested that the best pilot study sample size for a 300 and above study sample size would be between 10 to 50 . The participants contributed to the pilot study were different from the ones used in framework analysis.

Cronbach measurements indicate that a reliability of lower than 0.6 is considered poor, a reliability of approximately 0.7 is considered acceptable, while the reliability of higher than 0.8 is considered good. The results of the CA parameter can be seen in Table 5. The items have been proven to be reliable and understandable such that the scores based on the Cronbach's alpha test have successfully achieved above 0.7 . 
Table 5: Reliability Test Results

\begin{tabular}{|l|c|c|c|}
\hline Variables & Items & Alpha Value Pilot & Cronbach's Alpha \\
\hline Communication Skill Questions & 4 & 45 & 0.758 \\
\hline Motivation Skill Questions & 4 & 45 & 0.740 \\
\hline Teamwork Skill Questions & 4 & 45 & 0.732 \\
\hline Integrity Skill Questions & 4 & 45 & 0.712 \\
\hline Trust Skill Questions & 4 & 45 & 0.752 \\
\hline Honesty Skill Questions & 4 & 45 & 0.820 \\
\hline Attitude Skill Questions & 4 & 45 & 0.778 \\
\hline Learnability Skill Questions & 4 & 45 & 0.781 \\
\hline Innovation Skill Questions & 4 & 45 & 0.875 \\
\hline Responsibility Skill Questions & 4 & 45 & 0.732 \\
\hline Employability Questions & 15 & 45 & 0.753 \\
\hline
\end{tabular}

\section{Correlation test}

Correlation test measures the relationship strength between or among study variables (Crawford, 2006). Table 6 shows the results of the correlation between the study variables which indicate the existence of a positive relationship between the variables and the dimensions of the study at 0.05 level of significance. This contributes to providing initial support for the study hypotheses. In addition, these results indicate that the data are valid for conducting other statistical analyses, especially testing the study hypotheses.

Table 6: Correlation Analysis Results

\begin{tabular}{|l|c|c|c|c|c|c|c|c|c|c|c|}
\hline & $\mathbf{1}$ & $\mathbf{2}$ & $\mathbf{3}$ & $\mathbf{4}$ & $\mathbf{5}$ & $\mathbf{6}$ & $\mathbf{7}$ & $\mathbf{8}$ & $\mathbf{9}$ & $\mathbf{1 0}$ & $\mathbf{1 1}$ \\
\hline 1. Attitude & $\mathbf{1}$ & & & & & & & & & & \\
\hline 2. Communication & 0.167 & 1 & & & & & & & & & \\
\hline 3. Employability & 0.758 & 0.324 & 1 & & & & & & & & \\
\hline 4. Honesty & 0.075 & 0.210 & 0.145 & 1 & & & & & & & \\
\hline 5. Innovation & 0.527 & 0.167 & 0.366 & 0.224 & 1 & & & & & & \\
\hline 6. Integrity & 0.306 & 0.276 & 0.262 & 0.061 & 0.410 & 1 & & & & & \\
\hline 7. Learnability & 0.681 & 0.120 & 0.203 & -0.097 & 0.528 & 0.229 & 1 & & & & \\
\hline 8. Motivation & 0.311 & 0.329 & 0.271 & 0.253 & 0.510 & 0.612 & 0.166 & 1 & & & \\
\hline 9. Responsibility & -0.011 & 0.433 & 0.172 & 0.419 & 0.239 & 0.234 & -0.034 & 0.257 & 1 & & \\
\hline 10. Teamwork & 0.473 & 0.232 & 0.487 & 0.133 & 0.124 & 0.312 & 0.472 & 0.286 & 0.281 & 1 & \\
\hline 11. Trust & 0.06 & 0.443 & 0.196 & 0.439 & 0.132 & 0.204 & -0.146 & 0.312 & 0.413 & 0.064 & 1 \\
\hline
\end{tabular}

\section{Convergent and discriminant validity}

Convergent and discriminant validity methods were utilised to confirm the constructs validity for each study scale. Convergent validity is a method used or measuring the correlation level of multiple indicators of the same construct that are in agreement. Convergent validity was analysed using three indicators: AVE, loading factor, and CR. For each item, loading factors must be greater than 0.5 (Fornell \& Larcker, 1981). Hence, four questions were removed $(6,17,22,40)$ since the loading factor of these items were below 0.4. The AVE must be more than 0.5, and the CR, Cronbach's Alpha, must be more than 0.7 so that it is adequate for convergent validity (Hair et al., 2014). Table 7 illustrates that all the results were accepted, which indicates the convergent validity for all study items. 
Table 7: Convergent Validation Analysis

\begin{tabular}{|l|c|c|c|c|}
\hline Items & $\begin{array}{c}\text { Cronbach's } \\
\text { Alpha }\end{array}$ & Composite Reliability & AVE & AVE (SQRT) \\
\hline Trust & 0.712 & 0.767 & 0.554 & 0.744 \\
\hline Honesty & 0.774 & 0.770 & 0.653 & 0.808 \\
\hline Responsibility & 0.782 & 0.755 & 0.538 & 0.733 \\
\hline Communication Skills & 0.762 & 0.781 & 0.575 & 0.758 \\
\hline Teamwork & 0.743 & 0.734 & 0.584 & 0.764 \\
\hline Learnability & 0.759 & 0.861 & 0.675 & 0.822 \\
\hline Attitude & 0.789 & 0.863 & 0.612 & 0.782 \\
\hline Integrity & 0.708 & 0.820 & 0.533 & 0.730 \\
\hline Motivation & 0.785 & 0.808 & 0.514 & 0.717 \\
\hline Innovation & 0.798 & 0.714 & 0.559 & 0.748 \\
\hline Employability & 0.839 & 0.870 & 0.631 & 0.794 \\
\hline
\end{tabular}

Discriminate validity shows the degree of discrepancy between two study items designed to measure two theoretical concepts (Hatcher, 1994). Hence, this test was performed on the independent variables and the dependent variable using the Fornell-Lacker criterion method and the HeterotraitMonotrait ratio (HTMT) method, as seen in Table 8 and Table 9, respectively. The Fornell-Lacker criterion method compares the AVE square root with latent constructs correlation (Hair et al., 2014). A latent construct explains its indicator variance rather than other latent constructs variance. As a result, AVE square root value of each construct must be greater than the correlations with other latent constructs. It can be observed from Table 6 and Table 8, there was an increase in Cronbach's Alpha values between the pilot study analysis and final distributed survey due to the increase in study confidence and reliability.

\section{Table 8: Discriminant Validation using Fornell-Lacker Method}

\begin{tabular}{|l|c|c|c|c|c|c|c|c|c|c|c|}
\hline & $\mathbf{1}$ & $\mathbf{2}$ & $\mathbf{3}$ & $\mathbf{4}$ & $\mathbf{5}$ & $\mathbf{6}$ & $\mathbf{7}$ & $\mathbf{8}$ & $\mathbf{9}$ & $\mathbf{1 0}$ & $\mathbf{1 1}$ \\
\hline 1. Attitude & $\mathbf{0 . 7 8 2}$ & & & & & & & & & & \\
\hline 2. Communication & 0.167 & $\mathbf{0 . 7 5 8}$ & & & & & & & & & \\
\hline 3. Employability & 0.758 & 0.324 & $\mathbf{0 . 7 9 4}$ & & & & & & & & \\
\hline 4. Honesty & 0.075 & 0.210 & 0.145 & $\mathbf{0 . 8 0 8}$ & & & & & & & \\
\hline 5. Innovation & 0.527 & 0.167 & 0.366 & 0.224 & $\mathbf{0 . 7 4 8}$ & & & & & & \\
\hline 6. Integrity & 0.306 & 0.276 & 0.262 & 0.061 & 0.410 & $\mathbf{0 . 7 3 0}$ & & & & & \\
\hline 7. Learnability & 0.681 & 0.120 & 0.203 & -0.097 & 0.528 & 0.229 & $\mathbf{0 . 8 2 2}$ & & & & \\
\hline 8. Motivation & 0.311 & 0.329 & 0.271 & 0.253 & 0.510 & 0.612 & 0.166 & $\mathbf{0 . 7 1 7}$ & & & \\
\hline 9. Responsibility & -0.011 & 0.433 & 0.172 & 0.419 & 0.239 & 0.234 & -0.034 & 0.257 & $\mathbf{0 . 7 3 3}$ & & \\
\hline 10. Teamwork & 0.473 & 0.232 & 0.487 & 0.133 & 0.124 & 0.312 & 0.472 & 0.286 & 0.281 & $\mathbf{0 . 7 6 4}$ & \\
\hline 11. Trust & 0.06 & 0.443 & 0.196 & 0.439 & 0.132 & 0.204 & -0.146 & 0.312 & 0.413 & 0.064 & $\mathbf{0 . 7 4 4}$ \\
\hline
\end{tabular}

Based on Table 8 and Table 9, the results showed that the value of AVE square root was greater than any latent variable measuring a different sub-concept, indicating discriminant validity for all scales. The HTMT method was used to further test the discriminant validity resulted in all values being less than 0.9 (Henseler et al., 2015), as seen in Table 9. 
Table 9: Discriminant Validation using HTMT Method

\begin{tabular}{|l|c|c|c|c|c|c|c|c|c|c|c|}
\hline & $\mathbf{1}$ & $\mathbf{2}$ & $\mathbf{3}$ & $\mathbf{4}$ & $\mathbf{5}$ & $\mathbf{6}$ & $\mathbf{7}$ & $\mathbf{8}$ & $\mathbf{9}$ & $\mathbf{1 0}$ & $\mathbf{1 1}$ \\
\hline 1. Attitude & & & & & & & & & & & \\
\hline 2. Communication & 0.419 & & & & & & & & & & \\
\hline 3. Employability & 0.419 & 0.312 & & & & & & & & & \\
\hline 4. Honesty & 0.767 & 0.416 & 0.321 & & & & & & & & \\
\hline 5. Innovation & 0.715 & 0.453 & 0.399 & 0.804 & & & & & & & \\
\hline 6. Integrity & 0.755 & 0.391 & 0.414 & 0.544 & 0.666 & & & & & & \\
\hline 7. Learnability & 0.294 & 0.237 & 0.626 & 0.364 & 0.569 & 0.518 & & & & & \\
\hline 8. Motivation & 0.288 & 0.173 & 0.746 & 0.180 & 0.192 & 0.160 & 0.653 & & & & \\
\hline 9. Responsibility & 0.158 & 0.881 & 0.805 & 0.168 & 0.174 & 0.214 & 0.619 & 0.878 & & & \\
\hline 10. Teamwork & 0.348 & 0.651 & 0.786 & 0.136 & 0.387 & 0.352 & 0.463 & 0.287 & 0.392 & & \\
\hline 11. Trust & 0.463 & 0.856 & 0.642 & 0.385 & 0.435 & 0.485 & 0.415 & 0.240 & 0.403 & 0.868 & \\
\hline
\end{tabular}

\section{SOFT SKILLS AND EMPLOYABILITY DESCRIPTION AND EVALUATION}

The interest of this section is to describe the level of responses of the study sample individuals and discuss them using the arithmetic mean and standard deviation related to the explanatory axis soft skills variables and employability, as seen in Figure 4.

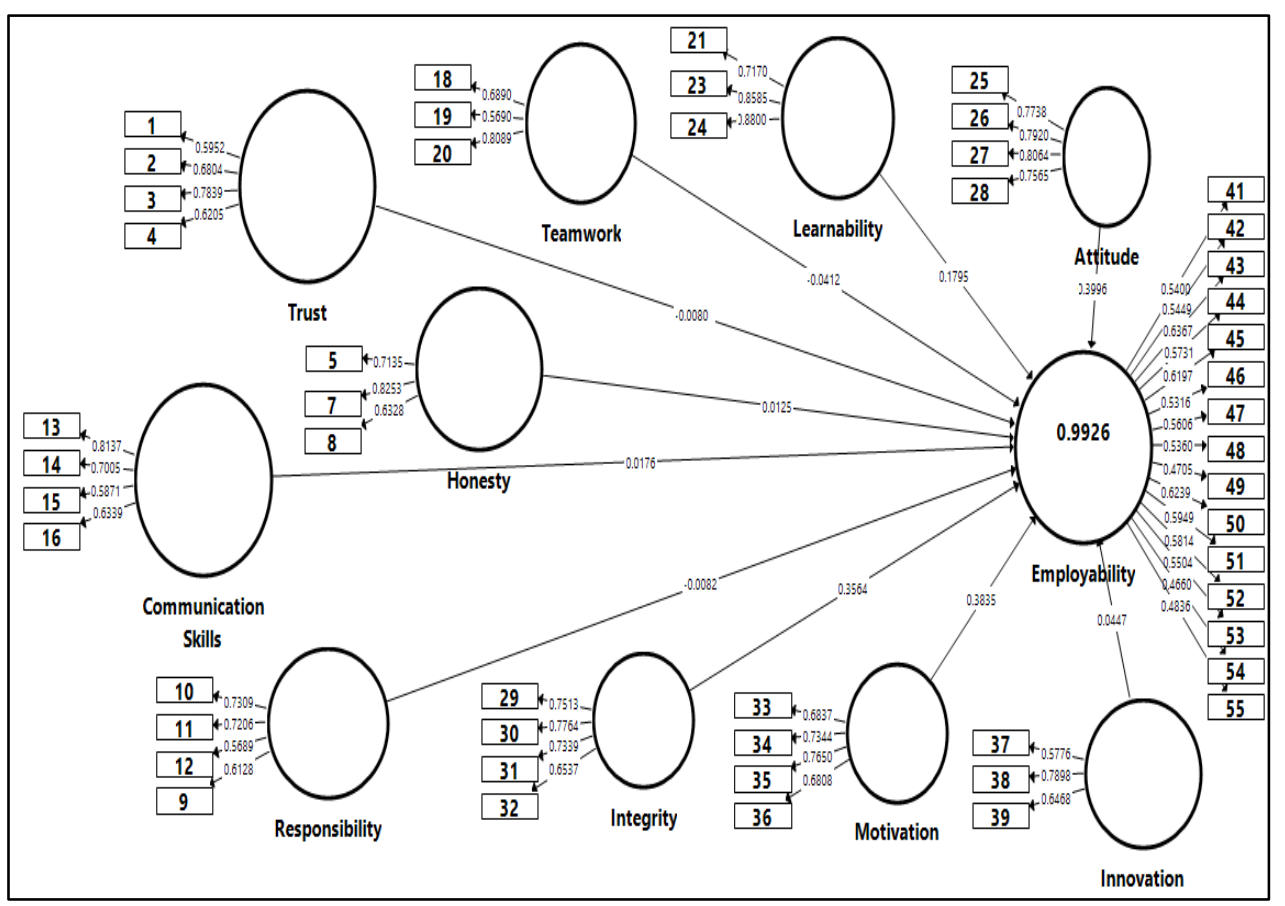

Figure 4: Significance Assessment of the Structural Model

\section{ASSESSMENT OF THE SEM SIGNIFICANCE}

The structure model describes causal relations between various constructs (independent, moderating, control, and dependent variables) to test the formulated hypotheses of the study. Hair et al. (2014) indicated that path analysis (analysed using a one-tail test) including the beta coefficient, standard error, t-value, $\mathrm{p}$-value, $\mathrm{f} 2, \mathrm{R} 2$, and $\mathrm{Q} 2$ are important criteria for assessing the structural model in PLS- 
SEM. Henseler et al. (2015) argued that the Goodness-of-fit (GoF) index is not suitable for model validation in PLS with simulated data, as it cannot separate valid models from invalid ones, thus it was not reported in this study.

In this research, ten hypotheses were utilized to answer the research questions outlined. For the hypotheses testing, parameter estimates for statistical significance together with the coefficient values were examined through a bootstrapping method based on PLS-SEM (Hair et al., 2014). The bootstrapping method with 1000 (Two-tailed, 0.05; 345 case data) bootstrap re-sampling and bias-corrected confidence intervals were utilised to examine the path coefficients significance (Chan et al., 2007; Ramayah et al., 2017). The t-value for the two-tailed test must be equal to or greater than 1.96 at a 5\% significance level (Hair et al., 2014; Tabachnick \& Fidell, 2013).

Table 10: Hypotheses Tests of Study

\begin{tabular}{|l|l|c|c|c|}
\hline Hypothesis & Hypotheses & T Statistics & P Values & Result \\
\hline H1 & Trust -> Employability & 1.208 & 0.228 & Unsupported \\
\hline H2 & Honesty -> Employability & 1.89 & 0.059 & Unsupported \\
\hline H3 & Responsibility - Employability & 1.14 & 0.255 & Unsupported \\
\hline H4 & Communication Skills - > Employability & 2.378 & 0.018 & Supported \\
\hline H5 & Teamwork -> Employability & 3.048 & 0.002 & Supported \\
\hline H6 & Learnability - - Employability & 5.71 & 0.000 & Supported \\
\hline H7 & Attitude -> Employability & 11.816 & 0.000 & Supported \\
\hline H8 & Integrity -> Employability & 11.878 & 0.000 & Supported \\
\hline H9 & Motivation -> Employability & 14.201 & 0.000 & Supported \\
\hline H10 & Innovation - > Employability & 1.577 & 0.115 & Unsupported \\
\hline
\end{tabular}

Initially, H4 expects communication skills to influence Employability. The results in Table 10 demonstrate a significant positive relationship between communication skills and Employability, hence, H4 is supported. H5 predicts that Teamwork influences Employability. The results showed that relation of this variable is numerically important at level of significance 5\%, which indicates that $\mathrm{H} 5$ is supported. Furthermore, H6 predicts that Learnability influences Employability; results showed that relation of this variable is numerically important at level of significance $5 \%$, which makes H6 supported. $\mathrm{H} 7$ assumed that there is a relation between attitude and employability. Statistics-t in Table 10 demonstrates a strong relation between attitude and employability, hence, $\mathrm{H} 7$ is supported. Furthermore, $\mathrm{H} 8$ assumes there is a relation between integrity and employability, the results showed a strong positive relation, which makes H8 supported. Finally, the results showed H9 is supported, which assumed there is a relation between motivation and employability.

However, the results revealed that the relationship is not significant between trust and employability, which makes H1 not supported. Similarly, in examining the relationship between honesty and Employability, the results showed that honesty does not have a positive significant relationship with Employability, hence, $\mathrm{H} 2$ was not supported. Moreover, in examining the relationship between Responsibility and Employability, the results indicated that Responsibility has no positive relationship with Employability, and H3 was not supported. Finally, Table 10 demonstrated that there is no relation between employability and innovation, which made H10 not supported.

\section{COEFFICIENT OF DETERMINATION $R^{2}$}

A necessary condition for the analysis of the PLS-SEM structural model is coefficient of determination $\left(\mathrm{R}^{2}\right)$. $\mathrm{R}^{2}$ explains the number of variations in a dependent variable by the regressors or independent variables (Hair et al., 2014). $\mathrm{R}^{2}$ ranges between the values of 0.000 to 1.000. A zero value indicates that there is no perfect relationship between the constructs. An $\mathrm{R}^{2}$ value of 1.000 indicates a perfect relationship, either positive or negative. This study has only one endogenous variable (Employability). Adjusted $\mathrm{R}^{2}$ considers the number of independent variables used for predicting the target variable, 
hence, it is an indicator to determine whether adding a new variable to the model will increase the model fit. $\mathrm{R}^{2}$ of Employability in this study was 0.993 . This result implies that the ten exogenous variables, combined in the model were able to explain about 0.993 percent of the variations in the dependent variable (Employability).

\section{ASSESSMENT OF EFFECT SIZE $\left(F^{2}\right)$}

Effect size $\left(\mathrm{f}^{2}\right)$ is another criterion for structural model evaluation in PLS-SEM. It is used to evaluate the size of the predicting variables or constructs. It evaluates the relative impact and size of each of the predictors on the dependent variable. This study used the $\mathrm{f}^{2}$ to assess the relative impact of the independent variables on the endogenous construct (Employability). Hair et al. (2014) stated that values of $0.02,0.15$, and 0.35 are used to assess effect size of a model. As shown in Figure 5, the results indicated that most of the exogenous constructs have small effect sizes on their respective endogenous construct. However, four variables have had a major impact on Employability: Attitude, Integrity, Learnability, and Motivation.

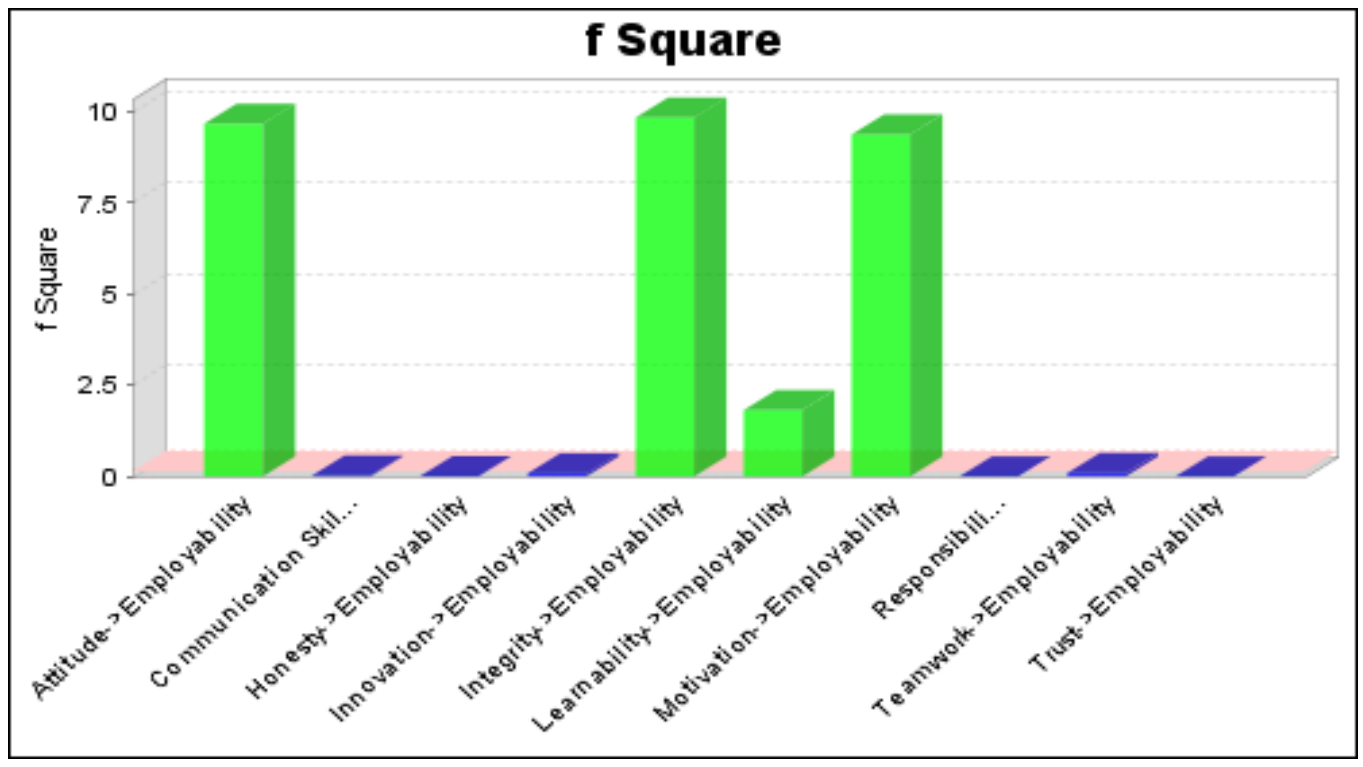

Figure 5: Results of $\mathrm{f}^{2}$ Analysis

Importance-performance Map refers to the size of the effect of each variable on the dependent variable in terms of the degree of importance. It can be seen that there is a difference in the size of the effect between the variables, but the most influential variables are: Attitude, Integrity, Learnability, and Motivation, and this proves the results of $\mathrm{f}^{2}$, as seen in Table 11 and Figure 6.

Table 11: Importance-Performance Map Results

\begin{tabular}{|l|c|}
\hline Variables & Employability \\
\hline Attitude & 0.393 \\
\hline Motivation & 0.376 \\
\hline Integrity & 0.363 \\
\hline Learnability & 0.182 \\
\hline Innovation & 0.046 \\
\hline Communication Skills & 0.015 \\
\hline Honesty & 0.011 \\
\hline Trust & -0.009 \\
\hline Responsibility & -0.013 \\
\hline Teamwork & -0.04 \\
\hline
\end{tabular}




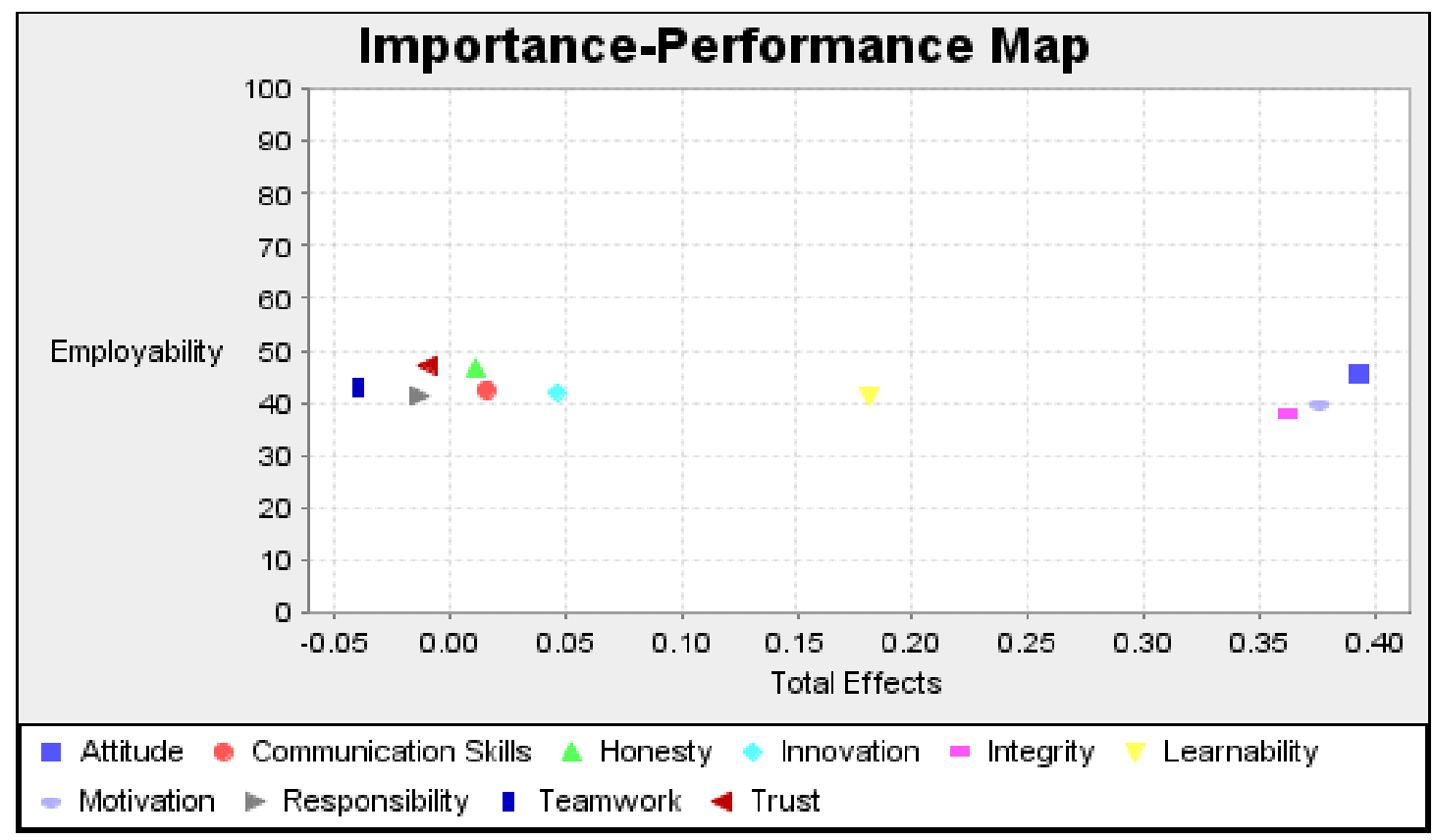

Figure 6: Importance-Performance Map Distribution

\section{PREDICTIVE RELEVANCE (Q⿻)}

Predictive Relevance $\left(\mathrm{Q}^{2}\right)$ is a measure to evaluate the inner model's predictive relevance. This measure is based on a sample technique called Blindfolding. This technique works on excluding part of the data matrix, estimating the model parameters, and predicting the excluded part (Hair et al., 2014). When the result value of $\mathrm{Q}^{2}$ is greater than zero for a particular endogenous construct, this indicates the predictive relevance path model for this construct. The measured value of $\mathrm{Q}^{2}$ for this study was 0.192 , which is higher than zero. This indicates how well a model predicts the data of omitted cases, which is reflected in the increased predictive relevance of the study variables regarding the effect of soft skills on employability.

\section{DISCUSSION OF FINDINGS}

The objectives of this research with the methods used to achieve them can be summarized in Table 12. The first objective was achieved through Fuzzy Delphi Analysis and resulted in ten critical soft skills. The second objective was achieved through SmartPLS analysis and resulted in six accepted hypotheses, as seen in Table 13.

Table 12: Research Objectives and Findings Summary

\begin{tabular}{|l|c|c|}
\hline Objective & Method & Results \\
\hline $\begin{array}{l}\text { To identify the critical soft skills } \\
\text { required by industry sector in Ma- } \\
\text { laysia based on Fuzzy Delphi } \\
\text { Analysis. }\end{array}$ & Fuzzy Delphi Analysis & Ten critical soft skills \\
\hline $\begin{array}{l}\text { To investigate the impact and im- } \\
\text { portance of soft skills on employ- } \\
\text { ability and define the most influ- } \\
\text { encing soft skills. }\end{array}$ & SmartPLS Analysis & $\begin{array}{c}\text { The most influencing soft skills on } \\
\text { employability are Motivation, Learna- } \\
\text { bility, Integrity, and Attitude }\end{array}$ \\
\hline
\end{tabular}


Table 13: Summary of Accepted Hypotheses

\begin{tabular}{|c|l|c|}
\hline H & Hypotheses & Results \\
\hline H4 & There is a relationship between Communication skills and Employability & Supported \\
\hline H5 & There is a relationship between Teamwork and Employability & Supported \\
\hline H6 & There is a relationship between Learnability and Employability & Supported \\
\hline H7 & There is a relationship between Attitude and Employability & Supported \\
\hline H8 & There is a relationship between Integrity and Employability & Supported \\
\hline H9 & There is a relationship between Motivation and Employability & Supported \\
\hline
\end{tabular}

It can be seen from Table 13, the accepted hypotheses were $\mathrm{H} 4, \mathrm{H} 5, \mathrm{H} 6, \mathrm{H} 7, \mathrm{H} 8, \mathrm{H}$, while the other hypotheses were rejected. The other rejected hypotheses might be impactful on employability since trust, honesty, responsibility, and innovation are important soft skills. However, communication skills, teamwork, learnability, attitude, integrity, and motivation were considered more important than the other soft skills. This does not affect the importance of the rejected skills; it indicates that the accepted skills are the critically impactful skills in technology industry based on experts' feedback and sample data analysis results. These skills must be targeted for graduates' development to increase the competency level of those who want to find a job in this industry.

Soft skills became significantly critical in various workplaces, particularly from career success and employability perspectives (Caggiano et al., 2020). The demand of the employers indicates that occupation-specific skills, i.e., hard skills, are not adequate for graduates to be engaged with today's labour market requirements. Employers have a preference to employ graduates with quick learning skills, flexibility, and adaptability to manage market changes and thrive on it (Suarta et al., 2017). The contributing factors for fresh graduates' unemployment were due to the insufficient communication skills (Ahmad, 2013; Rahman et al., 2017). Robles (2012), in her research, suggested that communication skills and integrity were the top two soft skills required by employees in today's labour market. Based on the specifications in the job advertisements, learnability and teamwork are also important skills which are demanded by the industry (Ooi \& Ting, 2017). It has been concluded that communication skills and teamwork are the most wanted skills in $21^{\text {st }}$ century workplace (Abelha et al., 2020; Suarta et al., 2017). A study conducted by the Institute of Leadership and Management, United Kingdom, emphasised that it is the employer's responsibility to maintain the trust level in an organisation by managers and leaders being honest with their employees. Furthermore, this study indicated that the integrity of the employees will be increased as long as they trust their leaders (Institute of Leadership \& Management [ILM], 2014). This is aligned with the findings of this research, trust and honesty were not considered important and impactful on employability, since it is an employer's responsibility to maintain them.

In Malaysia, soft skills will increase employment opportunities and attract organizations, as it is considered one of the strengths that can be used in finding suitable job opportunities in Malaysia. Human resources should be assessing the critical soft skills availability with each job candidate to be well prepared for job tasks and challenges. For instance, communication skills have a vital role in any organisation in terms of productivity and efficiency. The lack of communication skills was reported to be one of the main reasons of high rates of unemployment of graduates in Malaysia (Nesaratnam et al., 2020). Teamwork and Learnability are required in the industrial workforce of Malaysia, however, there was a significant difference between the expected level of skills availability among graduates and the actual competency level (Kenayathulla et al., 2019). Motivation was a point of concern from Malaysian industry perspective. As a result, it was considered as an essential role in human learning process (Razali et al., 2020). Attitude was reported to be a critical stone in industrial environment of Malysia, since it determines the behaviour of humans in terms of productivity and performance (S. M. Ishak, 2017). Finally, Integrity of employees is a critical skill that requires better understanding to prevent organisational issues in terms of performance and reputation (Rahim et al., 2020). 
Fadhil, Ismail, \& Alnoor

\section{CONCLUSION}

The issue of employability of Malaysian graduates and retaining employees has been studied for years, because of the shortage in soft skills among graduate students from education institutions. The importance of soft skills for the technology industry sector success and development has been discussed globally in recent years. This research was conducted to explore the importance of soft skills and the way through which it has been trained in the industries and training institutes to influence employability. Hard skills are another necessary aspect of employability that guide the employee to work in certain circumstances. However, the training institutes consider mainly the hard skills as the graduation requirement, and hence students and graduates lack soft skills, which creates a difficulty in getting employment. After conducting the statistical analysis of the questionnaire, the results demonstrated the influence of the critical soft skills on employability in technology industry sector of Malaysia. In conclusion, the employability and job competency are highly dependent on the following soft skills, namely, communication skills, teamwork, learnability, motivation, attitude, and integrity.

\section{REFERENCES}

Abelha, M., Fernandes, S., Mesquita, D., Seabra, F., \& Ferreira-Oliveira, A. T. (2020). Graduate employability and competence development in higher education - A systematic literature review using PRISMA. Sustainability, 12(15), 5900. https://doi.org/10.3390/su12155900

Adnan, A. H. M., Ramalingam, S., Ilias, N., \& Tahir, T. M. (2014). Acquiring and practicing soft skills: A survey of technical-technological undergraduates at a Malaysian tertiary institution. Procedia - Social and Behavioural Sciences, 123, 82-89. https://doi.org/10.1016/j.sbspro.2014.01.1400

Adnan, Y. M., Daud, M. N., Alias, A., \& Razali, M. N. (2017). Importance of soft skills for graduates in the real estate programmes in Malaysia. Journal of Surveying, Construction and Property, 3(2), 1-13. https://doi.org/10.22452/jscp.vol3no2.4

Ahmad, S. B. S. (2013). Soft skills level of Malaysian students at a tertiary institution: A comparative case study based on gender, area of residence and type of schools. International Journal of Asian Social Science, 3(9), 1929-1937. https://econpapers.repec.org/article/asiijoass/2013 3ap 3a1929-1937.htm

Ajit, V., \& Deshmukh, P. B. (2013). Factors impacting employability skills of engineers. International Journal of Science and Research (IJSR), 2(4), 30-32. https:/ /www.ijsr.net/archive/v2i4/IJSRON2013697.pdf

Akoum, I. (2016). Research, development, and innovation in Malaysia: Elements of an effective growth model. Asian Economic and Financial Review, 6(7), 390-403. https://doi.org/10.18488/iournal.aefr/2016.6.7/102.7.390.403

AlQudah, M. K., Osman, A., \& Safizal, A. (2014). Critical success factors of organizational performance: A study of small and medium enterprises in Jordan. IOSR Journal of Humanities and Social Science, 19(6 v.1), 5357. https://doi.org/10.9790/0837-19615357

Balcar, J. (2016). Is it better to invest in hard or soft skills? The Economic and Labour Relations Review, 27(4), 453470. https://doi.org/10.1177/1035304616674613

Becker, G. S. (2009). Human capital: A theoretical and empirical analysis, with special reference to education. University of Chicago Press. https://press.uchicago.edu/ucp/books/book/chicago/H/bo3684031.html

Boe, T. A. (2002). Gaining and/or maintaining employee trust within service organizations [Master Thesis. Menomonie, Wisconsin: University of Wisconsin-Stout]. https://minds.wisconsin.edu/bitstream/handle/1793/40307/2002boet.pdf

Bridgstock, R. (2009). The graduate attributes we've overlooked: Enhancing graduate employability through career management skills. Higher Education Research \& Development, 28(1), 31-44.

https://doi.org/10.1080/07294360802444347

Brown, J. D. (2002). The Cronbach Alpha reliability estimate. JALT Testing \& Evaluation SIG Newsletter, 6(1), $17-$ 19. https://hosted.jalt.org/test/bro 13.htm 
Brown, P., Hesketh, A., \& Wiliams, S. (2003). Employability in a knowledge-driven economy. Journal of Education and Work, 16(2), 107-126. https://doi.org/10.1080/1363908032000070648

Caggiano, V., Schleutker, K., Petrone, L., \& González-Bernal, J. (2020). Towards identifying the soft skills needed in curricula: Finnish and Italian students' self-evaluations indicate differences between groups. Sustainability, 12(10), 4031. https://doi.org/10.3390/su12104031

Carver, C. S., \& Scheier, M. F. (1982). Control theory: A useful conceptual framework for personality-social, clinical, and health psychology. Psychological Bulletin, 92(1), 111-135. https://doi.org/10.1037/00332909.92.1.111

Chan, F., Lee, G. K., Lee, E.-J., Kubota, C., \& Allen, C. A. (2007). Structural equation modelling in rehabilitation counselling research. Rehabilitation Counselling Bulletin, 51(1), 44-57. https://doi.org/10.1177/00343552070510010701

Chang, P.-L., \& Hsu, C.-W. (2011). An assessment model for hydrogen fuel cell applications: Fuzzy Delphi approach. International Journal of Social Science and Humanity, 1(3), 218-223. https://doi.org/10.7763/IJSSH.2011.V1.38

Chen, C.-T. (2000). Extensions of the TOPSIS for group decision-making under fuzzy environment. Fuzzy Sets and Systems, 114(1), 1-9. https://doi.org/10.1016/S0165-0114(97)00377-1

Cheng, C.-H., \& Lin, Y. (2002). Evaluating the best main battle tank using fuzzy decision theory with linguistic criteria evaluation. European Journal of Operational Research, 142(1), 174-186. https://doi.org/10.1016/S0377-2217(01)00280-6

Chu, H.-C., \& Hwang, G.-J. (2008). A Delphi-based approach to developing expert systems with the cooperation of multiple experts. Expert Systems with Applications, 34(4), 2826-2840. https://doi.org/10.1016/j.eswa.2007.05.034

Cimatti, B. (2016). Definition, development, assessment of soft skills and their role for the quality of organizations and enterprises. International Journal for Quality Research, 10(1), 97-130. https://doi.org/10.18421/IJQR10.01-05

Clarke, M. (2018). Rethinking graduate employability: The role of capital, individual attributes and context. Studies in Higher Education, 43(11), 1923-1937. https://doi.org/10.1080/03075079.2017.1294152

Connelly, L. M. (2008). Pilot studies. Medsurg Nursing, 17(6), 411-412. https://www.proquest.com/openview $/ 553 \mathrm{~d} 762 \mathrm{f} 3224 \mathrm{a} 627486 \mathrm{acfbf1a} 7320 \mathrm{e} 0 / 1$ ?pq-origsite $=$ gscholar\&cbl $=30764$

Considine, J., Botti, M., \& Thomas, S. (2005). Design, format, validity and reliability of multiple choice questions for use in nursing research and education. Collegian, 12(1), 19-24. https://doi.org/10.1016/S13227696(08)60478-3

Crawford, S. L. (2006). Correlation and regression. Circulation, 114(19), 2083-2088. https://doi.org/10.1161/CIRCULATIONAHA.105.586495

Cronbach, L. J. (1946). Response sets and test validity. Educational and Psychological Measurement, 6(4), 475-494. https://doi.org/10.1177/001316444600600405

Dall'Amico, E., \& Verona, S. (2015, December). Cross-country survey on soft skills mostly required by companies to medium/ high skilled migrants: Methodological approach for a common framework of soft skills at work. Torino: Centro Estero Internazionalizzazione Piemonte (Ceipiemonte Scpa). http://valorize.odl.org/outputs/IO1 Framework soft skill Report.pdf

Delbecq, A. L., Van de Ven, A. H., \& Gustafson, D. H. (1975). Group techniques for program planning: A guide to nominal group and Delphi processes. Scott Foresman Company. https://sites.google.com/a/umn.edu/avandeven/publications/books/group-techniques-for-programplanning

Dillahunt, T. R., Ng, S., Fiesta, M., \& Wang, Z. (2016, February-March). Do massive open online course platforms support employability? Proceedings of the 19th ACM Conference on Computer-Supported Cooperative Work \& Social Computing (pp. 233-244). San Francisco, California: ACM. https://doi.org/10.1145/2818048.2819924 
Department of Statistics, Malaysia (DOSM). (2020, October 16). Information technology and communication satellite account 2019. https://www.dosm.gov.my/v1/index.php?r $=$ column/pdfPrev\&id=cHBrejFuMIVMdFZzc2VrNilIZEZQUT09

Drost, E. A. (2011). Validity and reliability in social science research. Education Research and Perspectives, 38(1), 105-124. https://www3.nd.edu/ ggoertz/sgameth/Drost2011.pdf

Fornell, C., \& Larcker, D. F. (1981). Structural equation models with unobservable variables and measurement error: Algebra and statistics. Journal of Marketing Research, 18(3), 382-388. https://doi.org/10.2307/3150980

Gibb, S. (2014). Soft skills assessment: Theory development and the research agenda. International Journal of Lifelong Education, 33(4), 455-471. https://doi.org/10.1080/02601370.2013.867546

Habibi, A., Jahantigh, F. F., \& Sarafrazi, A. (2015). Fuzzy Delphi technique for forecasting and screening items. Asian Journal of Research in Business Economics and Management, 5(2), 130-143. https://doi.org/10.5958/2249$\underline{7307.2015 .00036 .5}$

Hair, F., Jr., Sarstedt, M., Hopkins, L., \& Kuppelwieser, V. G. (2014). Partial least squares structural equation modeling (PLS-SEM): An emerging tool in business research. European Business Review, 26(2), 106-121. https://doi.org/10.1108/EBR-10-2013-0128

Hairi, F., Ahmad Toee, M. N., \& Razzaly, W. (2011, November). Employers' perception on soft skills of graduates: A study of Intel Elite soft skill training. Proceedings of the International Conference on Teaching \& Learning in Higher Education (ICTLHE 2011). https://core.ac.uk/download/pdf/12007206.pdf

Hamid, M. S. A., Islam, R., \& Manaf, N. H. A. (2014). Employability skills development approaches: An application of the analytic network process. Asian Academy of Management Journal, 19(1), 93-111. http://irep.iium.edu.my/40171/

Hassan, C. N. (2015). An evaluation of soft skills development of a degree programme in a public bigher education institution [Doctoral Thesis. Penang, Malaysia: Universiti Sains Malaysia]. http://eprints.usm.my/29865/1/CHE_NORLIA_HASSAN.pdf

Hatcher, M. (1994). Voting and priorities in health care decision making, portrayed through a group decision support system, using analytic hierarchy process. Journal of Medical Systems, 18(5), 267-288. https://doi.org/10.1007/BF00996606

Heijde, C. M. V. D., \& Van Der Heijden, B. I. (2006). A competence-based and multidimensional operationalization and measurement of employability. Human Resource Management, 45(3), 449-476. https://doi.org/10.1002/hrm.20119

Helmer-Hirschberg, O. (1967). Analysis of the future: The Delphi method. Santa Monica: Rand Corporation. https://www.rand.org/pubs/papers/P3558.html

Henseler, J., Ringle, C. M., \& Sarstedt, M. (2015). A new criterion for assessing discriminant validity in variancebased structural equation modelling. Journal of the Academy of Marketing Science, 43(1), 115-135. https://doi.org/10.1007/s11747-014-0403-8

Hoch, J. E. (2013). Shared leadership and innovation: The role of vertical leadership and employee integrity. Journal of Business and Psycbology, 28(2), 159-174. https://doi.org/10.1007/s10869-012-9273-6

Institute of Leadership \& Management (ILM) (2014). The truth about trust: Honesty and integrity at work. https://www.institutelm.com/static/uploaded/2fcb92ca-7b28-4283-baa7ec5866576f84.pdf

Ishak, A. H., Osman, M. R., \& Din, G. (2015). Expert consensus on dimensions of Islamic values in quality management practice: Analysis of fuzzy Delphi method. The Turkish Online Journal of Educational Technology (TOJET), 273-280. https://www.researchgate.net/profile/Amal-Ishak-2/publication/297766650 Expert consensus on dimensions of islamic values in quality management practice Analysis of fuzzy delphi method/links/5eab86f445851592d6ae6c5e/Expert-consensus-on-dimensions-ofislamic-values-in-quality-management-practice-Analysis-of-fuzzy-delphi-method.pdf

Ishak, S. M. (2017). Influence of knowledge, attitude, and skill of good agriculture practice on oil palm production in seedling assistance scheme in Malaysia [Master Thesis. Selangor, Malaysia: Universiti Putra Malaysia]. http://psasir.upm.edu.my/id/eprint/68738/ 
Ishikawa, A., Amagasa, M., Shiga, T., Tomizawa, G., Tatsuta, R., \& Mieno, H. (1993). The max-min Delphi method and fuzzy Delphi method via fuzzy integration. Fuz:y sets and systems, 55(3), 241-253. https://doi.org/10.1016/0165-0114(93)90251-c

Jackson, D. N. (1994). Jackson personality inventory-revised (JPI-R). Sigma Assessment Systems \& Research Psychologists Press Division. https://www.sigmaassessmentsystems.com/assessments/jackson-personalityinventory-revised/

Jonck, P. (2014). A human capital evaluation of graduates from the Faculty of Management Sciences employability skills in South Africa. Academic Journal of Interdisciplinary Studies, 3(6), 265-274. https://doi.org/10.5901/ajis.2014.v3n6p265

Joshi, A., Kale, S., Chandel, S., \& Pal, D. K. (2015). Likert scale: Explored and explained. British Journal of Applied Science \& Technology, 7(4), 396-403. https://doi.org/10.9734/BJAST/2015/14975

Kenayathulla, H. B., Ahmad, N. A., \& Idris, A. R. (2019). Gaps between competence and importance of employability skills: Evidence from Malaysia. Higher Education Evaluation and Development, 13(2), 97-112. https://doi.org/10.1108/HEED-08-2019-0039

Magnússon, Ó. Ö. (2017). Self-reported honesty and measured trust: An experiment in comparing head teachers' self-reported bonesty and trust as measured in job satisfaction survey in compulsory schools in Reykjavike, Iceland [Master Thesis. Warwick, United Kingdom: University of Warwick]. https://skemman.is/bitstream/1946/31657/1/MA EdLeadMan Omar Orn Magnusson.pdf

Manakandan, S. K., Rosnah, I., Mohd, R. J., \& Priya, R. (2017). Pesticide applicators questionnaire content validation: A fuzzy Delphi method. The Medical Journal of Malaysia, 72(4), 228-235.

Martin Sanchis, R. (2017). Internationally orientated higher education institutions \& graduate employability [BSc. Thesis. Enschede, Netherlands: University of Twente]. https://essay.utwente.nl/73442/

McLean, M., Abbas, A., \& Ashwin, P. (2012, June). Pedagogic quality and inequality in undergraduate degrees. International Research Seminar: Higher Education and Human Development. Bloemfontein, South Africa.

Mercer, S. L., Green, L. W., Cargo, M., Potter, M. A., Daniel, M., Olds, S., \& Reed-Gross, E. (2008). Reliabilitytested guidelines for assessing participatory research projects. In M. Minkler \& N. Wallerstein (Eds.), Community-based participatory research for healtb: From process to outcomes (pp. 407-418). Jossey-Bass. https://researchprofiles.canberra.edu.au/en/publications/reliability-tested-guidelines-for-assessing-participatoryresearc

Ministry of Higher Education Malaysia (MOHE) (2012). The national graduate employability blueprint 2012-2017. https://masurimasooded770.files.wordpress.com/2014/03/national-graduate-employability-blueprint2012-2017.pdf

Ministry of International Trade and Industry (MITI) (2018). Industry 4WRD: National policy on industry 4.0. https://www.miti.gov.my/miti/resources/National $\% 20$ Policy $\% 20$ on $\% 20$ Industry $\% 204.0 /$ Industry4WRD Final.pdf

Mohr, P., \& Seymore, R. (2018). Understanding micro-economics. Van Schaik Publishers.

Murry, J. W., Jr., \& Hammons, J. O. (1995). Delphi: A versatile methodology for conducting qualitative research. The Review of Higher Education, 18(4), 423-436. https://doi.org/10.1353/rhe.1995.0008

Nesaratnam, S., Salleh, W. H. W., Von Foo, Y., Hisham, W. M. W. S. W., Perdagangan, P., Damansara, P., \& Jaya, P. (2020). Enhancing English proficiency and communication skills among Malaysian graduates through training and coaching. International Journal of Learning and Development, 10(4), 1-21. https://doi.org/10.5296/ijld.v10i4.17875

Nizam, S., \& Badri, M. (2013). Enhancing individual employability skills: A case study of Universiti Teknologi MARA Pahang [Doctoral Thesis. Kedah, Malaysia: Universiti Utara Malaysia]. https://1library.net/document/yr6181oy-enhancing-individual-employability-skills-study-universiti-teknologi-pahang.html

Norizan, M., Siti Nurul, H., Mohamed Omar, H., \& Latif, M. H. (2018). Soft skills assessment between diploma and degree students during industrial training: An industry's observation. International Journal of Engineering \& Technology, 7(4.42), 186-190. https://www.sciencepubco.com/index.php/ijet/article/view/25710 
Ooi, K., \& Ting, S. (2017). Employers' emphasis on technical skills and soft skills in job advertisements. The English Teacher, 44(1), 12. https://www.semanticscholar.org/paper/Employers\%27-Emphasis-on-Technical-Skills-and-Soft-in-Ooi-Ting/23de3e755de1ef36cdac15032beac93954655c42

Organization for Economic Co-operation and Development (OECD) (2019). OECD economic surveys: Malaysia. http://www.oecd.org/economy/surveys/Malaysia-2019-OECD-economic-survey-overview.pdf

Paranjape, M. S. (2007). Determinants of employability of graduates: A case study of university of Mumbai. The Indian Journal of Labour Economics, 50(2), 331-346. https://www.econbiz.de/Record/determinants-ofemployability-of-graduates-a-case-study-of-university-of-mumbai-paranjape-madhu-sudhir/10003619726

Park, Y. (2020). The effects of leader-member exchange and employee learning on perceived employability. International Journal of Training and Development, 24(2), 105-117. https://doi.org/10.1111/ijtd.12174

Rahim, A., Omar, K., \& Kamaruddin, A. (2020). Integrity and employee job performance. Journal of Critical Reviews, 7(16), 517-521. http://www.jcreview.com/fulltext/197-1593590476.pdf

Rahman, N. A. A., Tan, K. L., \& Lim, C. K. (2017). Predictive analysis and data mining among the employment of fresh graduate students in HEI. AIP Conference Proceedings, 1891 (pp. 020007-1 - 020007-6). AIP Publishing LLC. https://doi.org/10.1063/1.5005340

Rahmat, N., Ayub, A. R., \& Buntat, Y. (2017). Employability skills constructs as job performance predictors for Malaysian polytechnic graduates: A qualitative study. Geografia-Malaysian Journal of Society and Space, 12(3), 154 - 167. https://ejournal.ukm.my/gmjss/article/view/17655

Raja, S., Imaizumi, S., Kelly, T., Narimatsu, J., \& Paradi-Guilford, C. (2013). Connecting to work: How information and communication technologies could help expand employment opportunities. World Bank Group. http://hdl.handle.net/10986/16243

Ramayah, T., Yeap, J. A., Ahmad, N. H., Halim, H. A., \& Rahman, S. A. (2017). Testing a confirmatory model of Facebook usage in SmartPLS using consistent PLS. International Journal of Business and Innovation, 3(2), 1 14. https://groups.google.com/group/pls-sem/attach/65d47d22d2e97/IJBI\%202017.pdf?part=0.1

Ramlee, I., \& Marinah, A. (2013). Estimating the returns of self-employed and salaried workers in Malaysia. Journal of Contemporary Issues Thought, 3, 127-137. https://ejournal.upsi.edu.my/index.php/JCIT/article/view/987/688

Razali, F., Manaf, U., \& Ayub, A. F. M. (2020). STEM education in Malaysia towards developing a human capital through motivating science subject. International Journal of Learning, Teaching and Educational Research, 19(5), 411-422. https://doi.org/10.26803/ijlter.19.5.25

Ringle, C. M., Wende, S., \& Will, A. (2005). SmartPLS 2.0 M3. Hamburg.

Robles, M. M. (2012). Executive perceptions of the top 10 soft skills needed in today's workplace. Business and Professional Communication Quarterly, 75(4), 453-465. https://doi.org/10.1177/1080569912460400

Rothwell, A., \& Arnold, J. (2007). Self-perceived employability: Development and validation of a scale. Personnel Review, 36(1), 23-41. https://doi.org/10.1108/00483480710716704

Rowe, G., \& Wright, G. (1999). The Delphi technique as a forecasting tool: Issues and analysis. International Journal of Forecasting, 15(4), 353-375. https://doi.org/10.1016/S0169-2070(99)00018-7

Seetha, N. (2014). Are soft skills important in the workplace? A preliminary investigation in Malaysia. International Journal of Academic Research in Business and Social Sciences, 4(4), 44-56. https://doi.org/10.6007/IJARBSS/v4-i4/751

Sekaran, U., \& Bougie, R. (2016). Research methods for business: A skill building approach. John Wiley \& Sons.

Selvadurai, S., Choy, E. A., \& Maros, M. (2012). Generic skills of prospective graduates from the employers' perspectives. Asian Social Science, 8(12), 295-303. https://doi.org/10.5539/ass.v8n12p295

Singh, R., Chawla, G., Agarwal, S., \& Desai, A. (2017). Employability and innovation: Development of a scale. International Journal of Innovation Science, 9(1), 20-37. https://doi.org/10.1108/IJIS-10-2016-0041

Suarta, I. M., Suwintana, I. K., Sudhana, I. F. P., \& Hariyanti, N. K. D. (2017, September). Employability skills required by the 21 st century workplace: A literature review of labour market demand. Proceedings of the 1 st 
Influence of Soft Skills on Employability

International Conference on Technology and Vocational Teachers (ICTV T 2017) (pp. 337-342). Yogyakarta, Indonesia: Atlantis Press. https://doi.org/10.2991/ictvt-17.2017.58

Sumanasiri, E. G. T., Yajid, M. S. A., \& Khatibi, A. (2015). Conceptualizing learning and employability "learning and employability framework." Journal of Education and Learning, 4(2), 53-63. https://doi.org/10.5539/jel.v4n2p53

Tabachnick, B. G., \& Fidell, L. S. (2013). Using multivariate statistics: International edition (6th ed.). Pearson. https://www.pearson.com/uk/educators/higher-education-educators/program/Tabachnick-Using-Multivariate-Statistics-International-Edition-6th-Edition/PGM1037856.html

Tapsir, S. H. (2017). Employability in Malaysia: Selected works. Kuala Lumpur: Ministry of Higher Education. http://mycc.my/document/files/PDF\%20Dokumen/Employability $\% 20$ in $\% 20 \mathrm{Malaysia} \% 20 \mathrm{Se}$ lected $\% 20$ Works.pdf

Tribble, L. S. (2009). The importance of soft skills in the workplace as perceived by community college instructors and industries [Doctoral Thesis. Mississippi State, MS: Mississippi State University]. https://ir.library.msstate.edu/handle $/ 11668 / 17062$

Tsai, H.-C., Lee, A.-S., Lee, H.-N., Chen, C.-N., \& Liu, Y.-C. (2020). An application of the fuzzy Delphi method and fuzzy AHP on the discussion of training indicators for the regional competition, Taiwan national skills competition, in the trade of joinery. Sustainability, 12(10), 4290. https://doi.org/10.3390/su12104290

Tsai, H.-Y., Chang, C.-W., \& Lin, H.-L. (2010). Fuzzy hierarchy sensitive with Delphi method to evaluate hospital organization performance. Expert Systems with Applications, 37(8), 5533-5541. https://doi.org/10.1016/i.eswa.2010.02.099

Van Loo, J. B., \& Rocco, T. S. (2004, March). Continuing professional education and human capital theory. Academy of Human Resource Development International Conference (AHRD) (pp. 98-105). Austin, TX: Academy of Human Resource Development. https://eric.ed.gov/?id=ED492127

Whitehurst, G. J. R. (2016, December). Grading soft skills: The Brookings soft skills report card. https://www.brookings.edu/research/grading-soft-skills-the-brookings-soft-skills-report-card/

Williams, A.-M. C. (2015). Soft skills perceived by students and employers as relevant employability skills [Doctoral Thesis. Minneapolis, MN: Walden University]. https://scholarworks.waldenu.edu/cgi/viewcontent.cgi?arti-

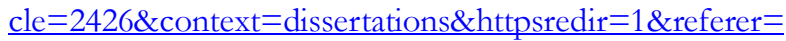

World Bank. (2020, June). Malaysia economic monitor: Surviving the storm. https://openknowledge.worldbank.org/bitstream/handle/10986/33960/149872.pdf? sequence=4\&isAllowed $=\mathrm{y}$

Yusoff, Y., Zaharim, A., Omar, M. Z., Mohamed, A., Muhamad, N., Mustapha, R., \& Rahmat, R. (2012). Engineering employability skills for Malaysian industry: Framework development. Proceedings of the $8^{\text {th }}$ WSEAS International Conference on Educational Technologies (pp. 36-47). http://www.wseas.us/e-library/conferences/2012/Porto/EDUTE/EDUTE-04.pdf

Zahari, A. I., Said, J., \& Arshad, R. (2019). Integrity climate questionnaire. Cogent Psychology, 6(1), 1626541. https://doi.org/10.1080/23311908.2019.1626541 


\section{APPENDIX A: NUMBER OF ARTICLES FOUND IN LITERATURE FOR EACH SOFT SKILL}

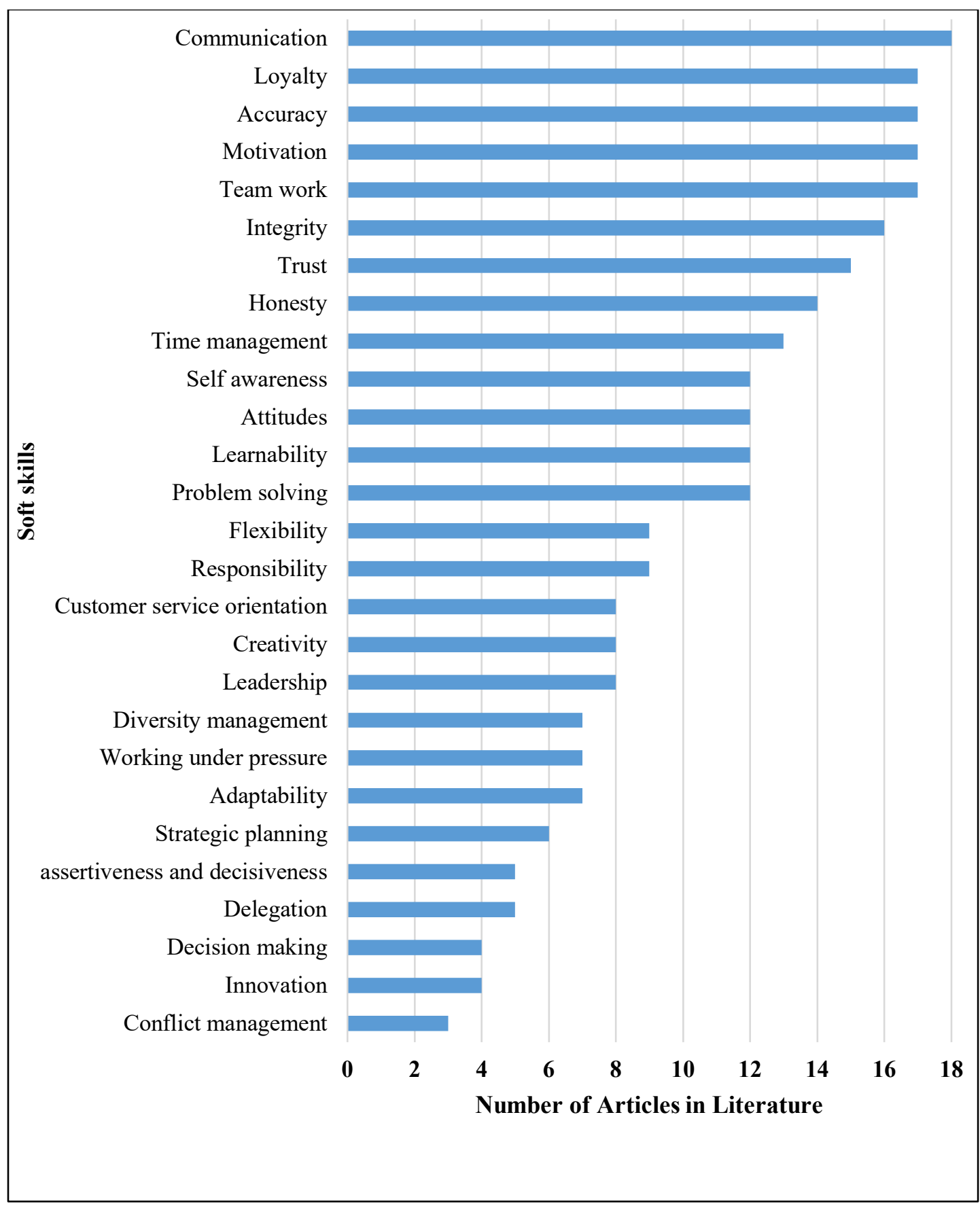

Figure A1: Number of Articles Found in Literature for each Soft Skill 


\section{Appendix B: The FuzZy Delphi METHOd Process}

The survey responses collected with those 15 experts in the preliminary study were compiled into a data set and analysed with the Fuzzy Delphi method, with Likert scale levels converted into different amounts of points and the linguistic variables expressed as a triangular fuzzy number (Joshi et al., 2015; H.-C. Tsai et al., 2020). Specifically, the analysis followed the steps below.

Step 1: Assume K experts were asked to assess the significance of the evaluation criteria and the ratings of alternatives using linguistic variables. In this step, the linguistic options represent the expert feedback regarding how important this item is. For example, the expert is expected to mark a level on the Likert scale that best reflects his/her opinion regarding communication skills.

Step 2: Convert linguistic variables to fuzzy triangular numbers. This research utilises 5-point Likert scale to represent experts' feedback, as seen in Table B1. Each value presented by the expert, was converted to a triple fuzzy value.

Table B1: Linguistic Variables and The Associated Fuzzy Scale

\begin{tabular}{|l|c|c|c|c|}
\hline Linguistic Variables & \multicolumn{3}{|c|}{ Fuzzy Scale } & Likert Scale \\
\hline Very important & 0.6 & 0.8 & 1 & 5 \\
\hline Important & 0.4 & 0.6 & 0.8 & 4 \\
\hline Neutral & 0.2 & 0.4 & 0.6 & 3 \\
\hline Not important & 0 & 0.2 & 0.4 & 2 \\
\hline Not important at all & 0 & 0 & 0.2 & 1 \\
\hline
\end{tabular}

Step 3: The distance between the average $\widetilde{r_{l j}}$ and $\widetilde{r_{l j}^{k}}$ and the distance between the average $\widetilde{w_{J}}$ and $\widetilde{w_{J}^{k}}$ for each expert was calculated using vertex method. Where $\mathrm{k}=1, \ldots, \mathrm{k}$. The distance between two fuzzy numbers $\tilde{m}=(\mathrm{m} 1, \mathrm{~m} 2, \mathrm{~m} 3)$ and $\tilde{n}=(\mathrm{n} 1, \mathrm{n} 2, \mathrm{n} 3)$ is computed by (Chen, 2000), as seen in Eq. 1.

$$
d(\tilde{m}, \tilde{n})=\sqrt{\frac{1}{3}\left[\left(m_{1}-n_{1}\right)^{2}+\left(m_{2}-n_{2}\right)^{2}+\left(m_{3}-n_{3}\right)^{2}\right]}
$$

Step 4: If the average distance and expert's evaluation is equal or less than 0.2 threshold, then the consensus is achieved (Cheng \& Lin, 2002). Furthermore, in between $m \mathrm{X} n$ score of alternative and $n$ criteria weight, if the percent of consensus is more than $75 \%$, then jump to step 5; else, repeat the steps (Chu \& Hwang, 2008; Murry \& Hammons, 1995).

Step 5: The fuzzy evaluations must be aggregated by Eq. 2 .

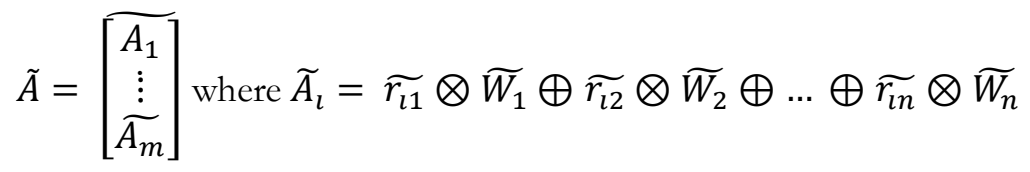

Step 6: The fuzzy evaluation $\widetilde{A_{l}}=\left(a_{i 1}, a_{i 2}, a_{i 3}\right)$ is defuzzified by Eq. 3 for each dimension. Based on $a_{i}$ values, the dimension options ranking can be defined.

$$
a_{i}=\frac{1}{4}\left(a_{i 1}+2 a_{i 2}+a_{i 3}\right)
$$




\section{APPENDIX C: STATISTICAL RESUlTS OF FUZZY DELPHI ANALYSIS}

The response consensus for the overall survey and for each soft skill parameter can be seen in Figure C1. The overall average of group consensus was $79 \%$, which makes this iteration accepted. If the average group consensus is greater than $75 \%$, then a consensus was achieved; if it is less than $75 \%$, another iteration of survey is required since consensus was not achieved (Chang \& Hsu, 2011; A. H. Ishak et al., 2015).

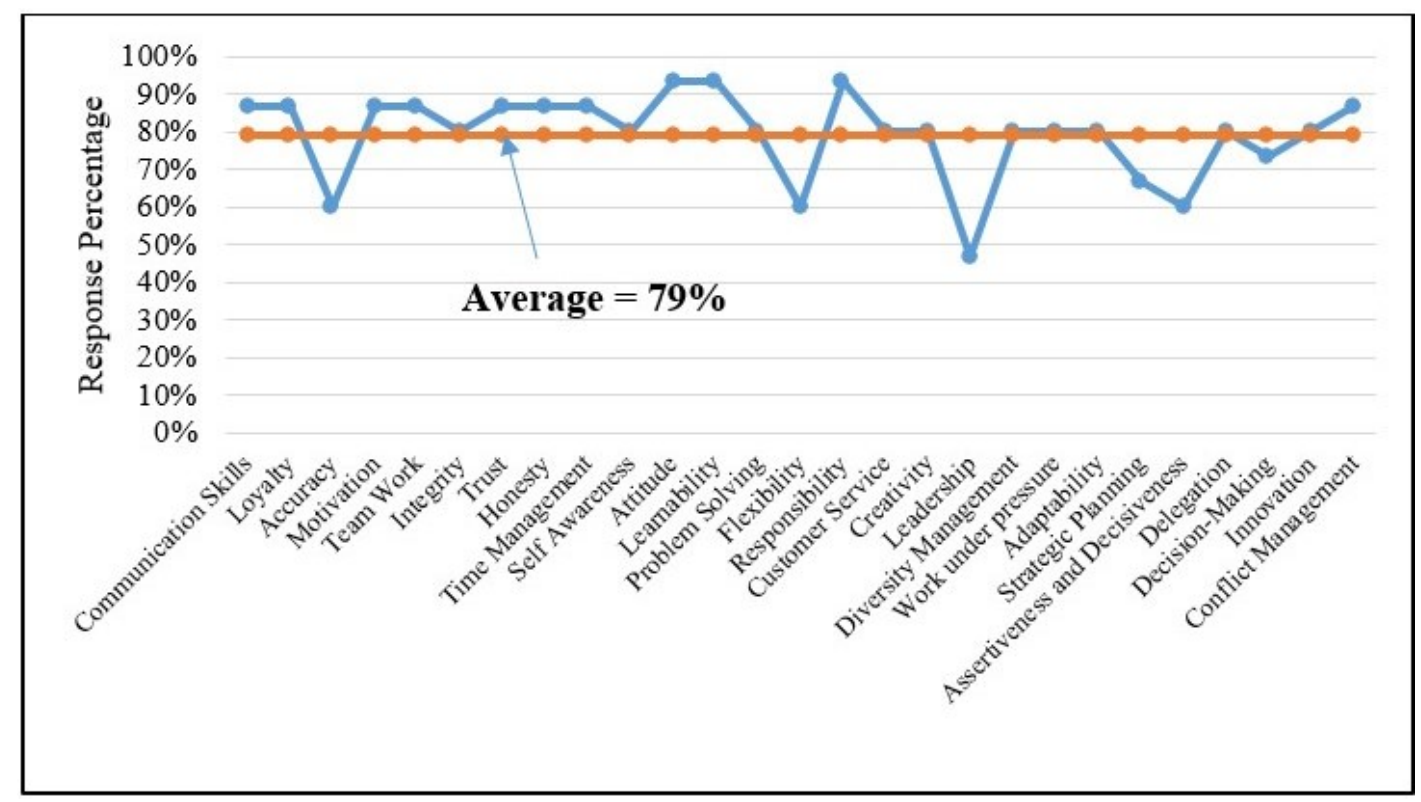

Figure C1: Fuzzy Delphi Consensus Average

After that, the threshold (d) value was calculated, which equals the distance between the average fuzzy view \& the experts' view. Decisions are made based on the value of $\mathrm{d}$, if $\mathrm{d}$ is lesser than the threshold of 0.2 , then this parameter will be accepted, since expert consensus was achieved. If $\mathrm{d}$ value is greater than 0.2, the parameter will be rejected (Chang \& Hsu, 2011; A. H. Ishak et al., 2015). Figure $\mathrm{C} 2$ shows all the 27 parameters (soft skills), the results showed a rejection of 17 dimensions and acceptance of 10 dimensions of soft skills. 


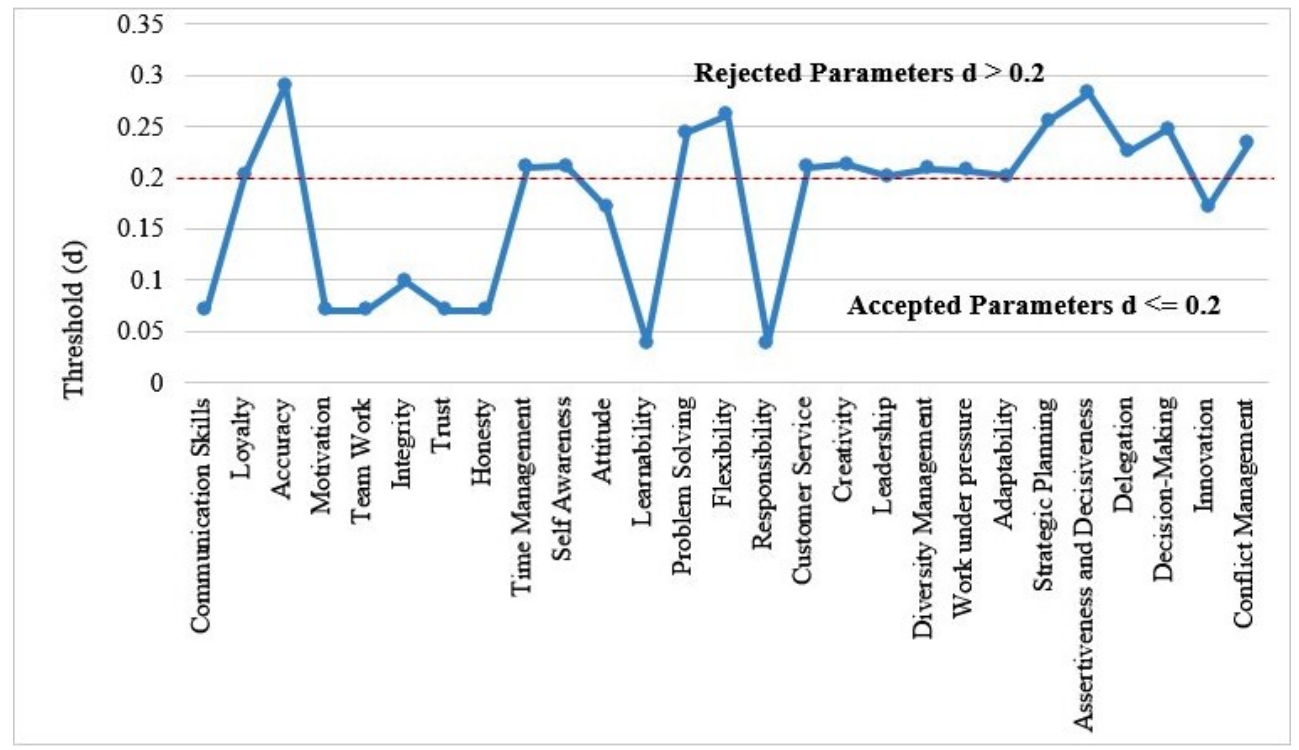

Figure C2: Rejected and Accepted Parameters Based on Threshold Value (d)

Based on Fuzzy Delphi's results, the most important critical dimensions of soft skills can be summarized with the threshold value (d) and the agreement percentages in Table $\mathrm{C} 1$. All the dimensions that had $<=0.2$ threshold, and $>=75 \%$ agreement were accepted. The rest of dimensions were rejected.

Table C1: Accepted Soft Skills Based on Fuzzy Delphi Analysis

\begin{tabular}{|l|c|c|}
\hline Soft Skill & d Value & Percentage of Agreement \\
\hline Communication skills & 0.071 & $87 \%$ \\
\hline Motivation & 0.071 & $87 \%$ \\
\hline Teamwork & 0.071 & $87 \%$ \\
\hline Integrity & 0.098 & $80 \%$ \\
\hline Trust & 0.071 & $87 \%$ \\
\hline Honesty & 0.071 & $87 \%$ \\
\hline Attitude & 0.171 & $93 \%$ \\
\hline Learnability & 0.038 & $93 \%$ \\
\hline Responsibility & 0.038 & $93 \%$ \\
\hline Innovation & 0.173 & $80 \%$ \\
\hline
\end{tabular}




\section{AUTHORS}

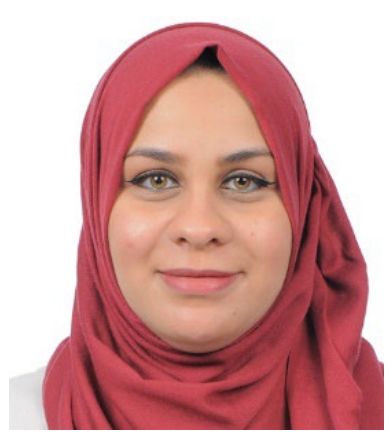

Sally S. Fadhil obtained her bachelor (Hons) degree from the University of Baghdad, Faculty of Business Management in 2014. She completed her master study from the Faculty of Management and Economics, Universiti Pendidikan Sultan Idris. She is passionate to complete her research career in the field of Organisation Management, Human Capital, and human resources.

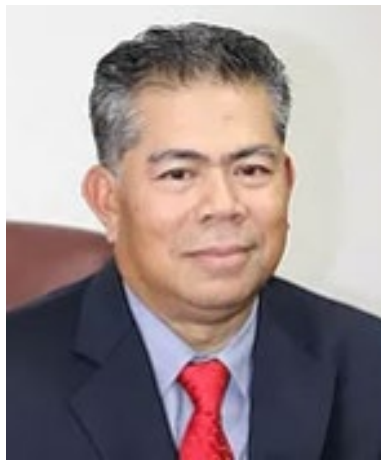

Ramlee Bin Ismail is an associate professor in the faculty of management and economics, Universiti Pendidikan Sultan Idris. He obtained his Ph.D. from university of Stirling, Scotland, United Kingdom in 2008. Currently, he is the dean of Institute of graduate studied of Universiti Pendidikan Sultan Idris. His research interests are in Economics of Education, Labour Economics, Return to Education, and Human Capital.

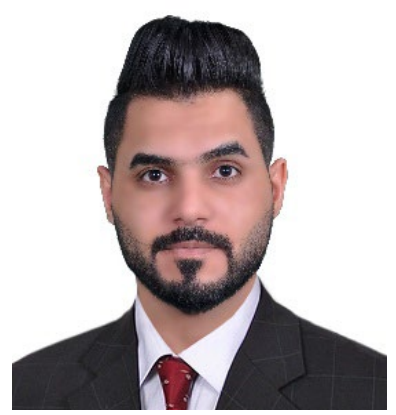

Alhamzah Alnoor is a senior lecturer in organization studies at the Southern Technical University in Iraq. He received his master's degree in business administration from the University of Basrah in Iraq. He is a Ph.D. student at the Universiti Sains Malaysia. His research interests include organizational studies and behaviour, leadership, innovation, and strategy management. 